\title{
THE EFFECTS OF TAI CHI ON QUALITY OF LIFE OF CANCER SURVIVORS: A SYSTEMATIC REVIEW AND META-ANALYSIS
}

\section{Authors:}

Xiaosha $\mathrm{Ni}^{1}$, Raymond Javan Chan ${ }^{2,3}$, Patsy Yates $^{2,4}$, Wenyi Hu${ }^{1}$, Xianhong Huang ${ }^{1}$, Yan Lou ${ }^{1 *}$

\section{Author affiliations:}

1. Hangzhou Normal University;

2. Queensland University of Technology;

3. Princess Alexandra Hospital;

4. Royal Brisbane and Women's Hospital

*Corresponding author: Yan Lou, lygreen0924@hotmail.com;+8615158898544;

Hangzhou Normal University, No.2318,Yuhangtang Rd, Cangqian, Yuhang District, 311121, Hangzhou, Zhejiang Province, P.R.China

ORCID:0000-0002-6844-1625 


\section{Abstract}

Purposes: To assess the effects of Tai Chi on quality of life (QOL) of cancer survivors.

Methods: The following databases were searched: Pubmed, Cochrane CENTRAL, EBSCO (including Medline, CINAHL and other databases), ScienceDirect, CNKI, Wangfang Data, and CQVIP until April 25th, 2018. Randomized Controlled Trials (RCTs) published in English or Chinese examining the effects of Tai Chi intervention for cancer survivors were included. The primary outcome was QOL; the secondary outcomes were limb function/muscular strength, immune function indicators, cancerrelated fatigue (CRF) and sleep disturbance. Methodological quality was assessed using the Cochrane Risk of Bias tool. Results of RCTs were pooled with mean difference (MD) or standardized mean difference (SMD) with 95\% confidence intervals (CI). Quality of evidence for each outcome was assessed with the GRADE system.

Results: Twenty-two RCTs were included in this review. Tai Chi improved the physical (SMD:0.34, 95\%CI:0.09,0.59) and mental health (SMD:0.60, 95\%CI:0.12,1.08) domains of quality of life. The intervention improved the limb/muscular function of breast cancer survivors (SMD:1.19, 95\% CI:0.63, 1.75), and in mixed samples of cancer survivors reduced the levels of cortisol (MD: -0.09, 95\%CI: -0.16, -0.02), alleviated CRF (SMD: -0.37, 95\%CI:-0.70,-0,04) and promoted sleep (SMD: -0.37, 95\%CI: -0.72, $-0.02)$.

Conclusion: There is low level evidence suggesting that Tai Chi improves physical and mental dimensions of QOL and sleep. There is moderate level evidence suggesting Tai Chi reduces levels of cortisol and CRF, and improves limb function. Additional studies with larger sample sizes and with higher-quality RCT designs comparing different regimens of Tai Chi are warranted.

Key words: Tai Chi, cancer survivors, quality of life, cancer-related fatigue, limb function, sleep. 


\section{Introduction}

While the incidence of cancer has increased in many countries, there has been a decrease in cancer death rates [1]. These changes have resulted in a growing population of cancer survivors. Studies indicate that many cancer survivors experience adverse effects relating to physical function, mental health, physical disability and difficulty in maintaining social activities [2]. These effects have significant impacts on quality of life (QOL) and in some cases survival. A 2011 systematic review reported that more than half of cancer patients use complementary therapies to manage these adverse effects, and to promote physical and psychological health, with mind-body exercise as commonly reported approaches [3].

Tai Chi (Chuan) is an ancient Chinese mind-body fitness regimen, which has been

widely studied to explore its benefits on human health $[4,5]$. Tai Chi is considered a moving meditation, in which practitioners are guided to be mindful of their postures, movements and breathing, with an intensive inwardly directed focus [6]. For the body, Tai Chi is a form of moderate intensity aerobic exercise (less than $55 \%$ of maximal oxygen intake), leading to more efficient breathing, better capacity to control posture, and enhanced cardiovascular function [7].

In recent years, there have been an increasing number of trials assessing the effects of Tai Chi as a non-pharmacological intervention among cancer patients [8]. A number of systematic reviews have been published since 2010 [9-15], and mostly focused on examining the benefits for breast cancer patients $[9-11,14,16]$. These reviews report non-significant effects of Tai Chi on most domains of QOL, except for the mental health domain $[9-11,16]$. Moreover, inconsistent results have been reported in terms of the effect of Tai Chi on muscle strength [14]. One of the earliest systematic reviews explored the combined effects of Tai Chi and Qigong for all types of cancer patients [17]. Tai Chi and Qigong share some commonalities, including the use of Ying and Yang as guided theory. Nevertheless, they differ in many ways [18]. Tai Chi was 
originally developed for martial purposes with a focus on body movement and exercise, while Qigong was developed for fitness regimen with an emphasis on body relaxation and mindfulness meditation [19]. As such, the combination of both therapies in an evidence review makes it difficult to isolate the effects of Tai Chi. Further, some of these reviews [15] did not include studies published in the Chinese language or included studies of patients both during and post-cancer treatment [9-12, 17], making it difficult to identify the efficacy of Tai Chi for patients finished treatment. In one study focused on breast cancer patients post treatment, results indicated a lack of benefits from Tai Chi on QOL $[13,14]$. Given the limitations of the existing reviews, the aim of this current systematic review and meta-analysis was to assess the effects of Tai Chi exercise in the population of cancer survivors.

\section{Methods}

The review was conducted and reported in accordance with the Cochrane Handbook for Systematic Reviews of Interventions [20] and the Preferred Reporting Items for Systematic Reviews and Meta-Analysis (PRIMSA) statement [21].

\section{Data sources and Search strategy}

The following databases were searched electronically up to $25^{\text {th }}$ April, 2018: MEDLINE (via PubMed, from 1997), Cochrane CENTARL (from 1996), EBSCO (from 1975), ScienceDirect (from 2006), Wanfang Data (from 1989, Chinese, 万方), VIP ( from 1989, Chinese, 维普网) and CNKI (China National Knowledge Infrastructure, from 1994, Chinese). The search terms included 'Tai Chi', 'Tai Chi Chuan’, ‘Tai Ji’, ‘Tai Ji Quan', ‘cancer’, ‘tumor’ and ‘carcinoma’’太极拳’, ‘太极’ ‘肿 瘤”, and ‘癌症, ‘癌”.

\section{Selection of studies}

All search results were imported into the NoteExpress software and screened for duplication. Two reviewers (NXs and HWy) independently pre-screened all articles 
(title and abstract) according to the inclusion criteria. Those identified for inclusion either by one reviewer or two reviewers were subject to a full-text review. Independent assessments of the included articles were conducted by the same two reviewers against the inclusion and exclusion criteria. Discrepancy was resolved by discussion and consensus.

\section{Inclusion criteria}

Eligibility criteria were detailed using the Participants, Interventions, Controls, Outcomes, and Studies (PICOS) framework. Participants were adults aged 18 years or older with a diagnosis of cancer (solid and hematologic); of any race, nationality or language background; had previously received cancer treatment; and without major concomitant chronic disease or mental illness that precluded them from participating in Tai Chi. The studies must have examined Tai Chi movement of any type as the only intervention, compared to usual care, or other standard interventions including health education, spiritual growth, psychological support, and daily exercise. The primary outcome of this review was QOL. Secondary outcomes included limb function, fatigue, sleep disturbance and immune function indicators. Only randomized controlled trials (RCTs) were included.

\section{Data extraction}

Two reviewers (NXs, HWy) independently extracted data from each included study using a pre-designed Microsoft Excel data extraction form. Disagreements were settled with a discussion with a third reviewer (LY).

\section{Risk of bias assessment and quality level of evidences}

The methodological quality of the studies was evaluated according to the Cochrane Handbook for Systematic Reviews of Interventions [20] (RevMan version 5.1.0, The Cochrane Collaboration, 2011). The risk of bias assessment included generation of the allocation sequence, allocation concealment, blinding of the participants and personnel, 
blinding of outcome assessors, selective outcome reporting, incomplete outcome data, and other potential sources of bias. Each risk of bias item was assessed as low, unclear or high risk of bias based on the trial reports. Two review authors (NXs, HWy) assessed the risk of bias for each study independently, with discussion in the presence of any disagreements to reach consensus. Further disagreement was resolved by discussion with a third reviewer. In addition to bias assessment to each study, we assessed the quality of evidence for each outcome variable using the Cochrane Collaboration Network GRADE (the Grading of Recommendations Assessment Development and Evaluation).

\section{Data synthesis and analysis}

Meta-analysis was conducted using Review Manager (version 5.3 for Windows, Cochrane Collaboration, http://tech.cochrane.org/revman). Statistical heterogeneity was determined using Q-test and the $\mathrm{I}^{2}$ statistic. For cases in which $\mathrm{P}<0.10$ and $\mathrm{I}^{2} \geq 50 \%$, a random effects model was applied. Otherwise, a fixed-effects model was used. Sensitivity analysis was applied to test the stability of the results if there was large heterogeneity. For continuous variables, weighted mean difference (WMD) was calculated when outcomes were measured using the same scale across studies, and the standardized mean difference (SMD) was applied when different scales were used in different trials. Publication bias was not assessed with a funnel plot since the number of studies included for each meta-analysis did not reach 10 [22].

\section{Results}

\subsection{Study selection}

In total, 476 citations were identified from the electronic database searches. Of these, 160 were removed for duplication. After screening the titles and abstracts, 51 studies were retrieved for full-text review. Of the 51, 22 [23-44] met the inclusion criteria and were included in this review (See Fig. 1 for reasons of excluded studies), of which 15 
studies [23-31, 34-39] were quantitatively synthesized. The remaining 7 studies [32-33, 40-44] reported varied outcome indicators making it insufficient for meta-analysis.

\subsection{Study characteristics}

Of the 22 included studies $(\mathrm{N}=1,410)$, eight were published in Chinese (all conducted in China) and 14 were published in English (three conducted in China, and 11 in the United States). Most studies ( $\mathrm{n}=18)$ were published after 2010 (See Table 1). The largest sample size in the included studies was 185 and the smallest was 16. Only one study [39] reported the method for sample size calculation. A variety of cancer diagnoses were recruited in the included studies, with breast cancer $(n=1,054)$ and lung cancer $(n=248)$ as the most common cancer types.

Of the 22 studies, 13 studies reported the use of 24-form Tai Chi based on Yang style, two studies with Tai Chi Chih Movements, one study with 24-form Tai Chi based on Chen style, and one with 10-form Tai Chi qigong based on simplified Tai Chi. Different forms of Tai Chi vary in the number of movements, the pace and power (See Table 2).

In the majority of studies, Tai Chi was instructed and guided by a professional coach, with the period of intervention being from 3 to 6 months, with a frequency of 3-5 sessions per week. All studies lasted less than 60 minutes for each session, with 10 to 20 minutes of warm-up inclusive. No adverse events were mentioned from the included studies, and the overall exercise compliance was good. Control groups included usual care, routine rehabilitation training, sham Tai Chi, aerobic exercise, health education, support group, psychological support or cognitive behavioral therapy.

\subsection{Risk of bias assessment}

The risk of bias assessment for each study is presented in Figure 3. The majority of studies were rated as low risk in the selective outcome reporting domain $(n=21)$. Around half of included studies were rated as low risk in the random sequence generation $(n=13)$ $[23-26,30,31,33,35,38,39,41,43-44]$, allocation concealment $(n=9)[23,30,31,35$, 
$38,39,41,44]$, and incomplete outcome data reporting domains $(\mathrm{n}=10)[30,32-36,38$, $39,42,44]$. Due to the nature of Tai Chi intervention, only a few studies reported blinding of participants and personnel $(n=3)$ [31, 38-39], and blinding of outcome assessment $(\mathrm{n}=6)[29,31,36,38-39,44]$. Therefore, most studies were rated as highrisk for these two domains.

\subsection{Data synthesis}

\section{4.1 Effects on quality of life}

Ten studies [23-32] assessed QOL, and one study [32] was not included for statistical pooling due to insufficient data provided. The meta-analysis found a significant improvement in physical functioning [Random effects model, SMD $=0.34,95 \% \mathrm{CI}$ $(0.09,0.59) ; \mathrm{P}=0.007]$ and mental functioning [Random effects model, $\mathrm{SMD}=0.60$, 95\% CI $(0.12,1.08), \mathrm{P}=0.01$ ], but not in social functioning [Random effect model, SMD $=0.26,95 \% \mathrm{CI}(-0.25,0.77) ; \mathrm{P}=0.32]$ for the Tai Chi group compared to the control group (See Table 3 and Appendix Fig. 1.1-1.3). Studies were removed one by one in sensitivity analysis for physical and mental functioning domains, but no significant improvement was detected. For the social functioning dimension, sensitivity analysis identified a significant improvement after the removal of two studies with small sample sizes (Appendix Fig.1.4) [29-30]. In light of the low methodological quality of the included studies and high level of heterogeneity, there is low level evidence suggesting that Tai Chi could improve the physical, mental and social domains of QOL (Table 4).

\section{4.2 Effects on Upper limb function and muscular strength}

A meta-analysis of five trials [24-28] including 465 breast cancer survivors for measures of upper limb function demonstrated significant heterogeneity $\left(\mathrm{I}_{2}=87 \%, \mathrm{P}<\right.$ 0.00001). The pooled results from the random effects model demonstrated significant differences in upper limb function scores between the Tai Chi intervention group and the control group, with the Tai Chi group having better limb function ( $\mathrm{SMD}=1.19,95 \%$ 
CI $[0.63,1.75] ; \mathrm{P}<0.0001$ ) (See Appendix Fig. 2.1). Except for an intervention period of three months in Wang et al's study [26], the remaining four studies all had an intervention period of 6 months. Sensitivity analysis was conducted after removing Want et al's study, resulting in statistical significance and consistency in the forest plot (See Appendix Fig. 2.2).

Four trials $[24-25,28,34]$ measured muscular strength of upper limbs of breast cancer survivors. There was no statistically significant heterogeneity among different trials $\left(\mathrm{P}=0.13, \mathrm{I}^{2}=47 \%\right)$. In a fixed-effects meta-analysis, a significant improvement $(\mathrm{SMD}=0.49 ; 95 \% \mathrm{CI}(0.16,0.81) ; \mathrm{P}=0.003)$ in muscular strength scores was found for the Tai Chi group compared to the control group (See Appendix Fig. 2.3). In the presence of heterogeneity, sensitivity analysis was conducted but did not change the result. Due to low methodological quality, the level of evidence for the positive effects of Tai Chi on limb function and muscular strength was moderate (See Table 4).

\section{4.3 Effects on Interleukin-6 (IL-6)}

Two trials [30, 35] compared the IL-6 levels of 18 participants in the Tai Chi group (combined) and 20 participants in the health education or standard support group (combined). There was no detected heterogeneity with the two trials $\left(\mathrm{Chi}^{2}=0.00\right.$, $\mathrm{P}=1.00 ; \mathrm{I}^{2}=0 \%$ ). The fixed-effects meta-analysis showed statistically significant difference between the Tai Chi and control group, with the control group associated with reduced IL-6 level $(\mathrm{MD}=2.21 ; 95 \% \mathrm{CI}(0.74,3.68) ; \mathrm{P}=0.003)$ (See Appendix Fig. 3.1). The evidence indicating effects of Tai Chi on IL-6 levels was low, because of the small sample size $(\mathrm{n}=38)$ and low methodological quality (See Table 4).

\section{4.4Effects on cortisol levels}

Two trials $[30,36]$ compared cortisol levels of participants with 38 participants in the Tai Chi group (combined) and 35 participants in the health education or standard support group (combined). There was no detected heterogeneity among the two trials 
$\left(\mathrm{Chi}^{2}=0.25, \mathrm{P}=0.62 ; \mathrm{I}^{2}=0 \%\right)$. The fixed-effects meta-analysis showed statistically significant difference between the Tai Chi and control group, with the Tai Chi group associated with reduced cortisol level $(\mathrm{MD}=-0.09,95 \% \mathrm{CI}(-0.16,-0.02) ; \mathrm{P}=0.01)$ (See Appendix Fig. 3.2). The quality of evidence for the benefits of Tai Chi for cortisol levels was moderate due to the small sample sizes in both studies (See Table 4).

\section{4.5 Effects on cancer related fatigue (CRF)}

Three trials [37-39] compared CRF in the two groups as measured by fatigue symptom severity with 115 participants in the Tai Chi group and 119 participants in the usual care group or Sham Qigong group. There was heterogeneity among the trials $\left(\mathrm{Chi}^{2}=10.21\right.$, $\mathrm{P}=0.006 ; \mathrm{I}^{2}=80 \%$ ), and thus sensitivity analysis was conducted with the exclusion of Michel et al's study. The fixed-effects meta-analysis suggests a significant difference between the Tai chi and control group, with the Tai Chi group associated with reduced CRF level (SMD=-0.37 , $95 \%$ CI $(-0.70,-0.04) ; \quad \mathrm{P}=0.03) \quad$ (See appendix Figures $4.1 \& 4.2$ ). The quality of evidence was moderate, as the processes of blinding and randomization were not clearly described (See Table 4).

\section{4.6 Effects on sleep quality}

Three trials [37-39] compared sleep quality as measured by the Pittsburgh Sleep Quality Index and Self-Rating Scale of Sleep with 106 participants in the Tai Chi group and 112 participants in the usual care group or Sham Qigong group. There was heterogeneity among the trials $\left(\mathrm{Chi}^{2}=33.82, \mathrm{P}<0.001 ; \mathrm{I}^{2}=94 \%\right)$. Due to the significant heterogeneity, sensitivity analysis was conducted with the exclusion of Michel et al's study. The fixed-effects meta-analysis suggests a significant difference between the Tai chi and control group, with the Tai Chi group associated with improved sleep levels $(\mathrm{SMD}=-0.37,95 \% \mathrm{CI}(-0.72,-0.02) ; \mathrm{P}=0.04)$ (See Appendix Figure 5.1\&5.2). The

evidence rating was low because of the small sample size and low methodological quality (See Table 4). 


\section{Discussion}

Several limitations of the available studies and notable risk of bias in many dimensions of assessment should be considered in the interpretation of these results. The current meta-analysis pooled results for three months following the intervention due to the insufficient data at six months. The long-term effectiveness of Tai Chi in cancer patients cannot yet be determined, although the results from several studies [23, 27] suggest better outcomes including shoulder function, postoperative upper limb edema, muscle strength, and psychological health among breast cancer patients at 6 months. Notwithstanding these limitations, this meta-analysis is unique in its focus on the effects of Tai Chi interventions on multiple outcomes for cancer survivors. Overall, the results indicate low to moderate level of evidence of the positive effects of Tai Chi.

\subsection{Assessment of the effects of Tai Chi on cancer survivors}

\subsubsection{Quality of Life}

Quality of life is a subjective and multi-dimensional concept [47]. While measurement scales differ slightly in terms of the domains assessed, physical, psychological or mental, social relationships and symptoms are the most commonly evaluated among cancer survivors [48-49].

Consistent with the findings from the meta-analyses of Zeng et al. [12] and Lee et al. [15], the current meta-analysis identified low level evidence that Tai Chi exercise has an overall positive effect on physical and psychological dimension of QOL among cancer survivors. There are several explanations for these findings. The 24-form Tai Chi based on Yang style was used most commonly in the studies included, which is considered more suitable for cancer survivors [45] for its ease of learning and smooth postures [46]. Importantly, Tai-Chi might be beneficial for cancer survivors because of its impact on subjective perceptions of wellbeing. According to Li Y. et al [50], Tai Chi practitioners often offer group sessions, in which people usually share a common 
interest, and this in turn can promote harmonious interpersonal relationships. While Campo et al. [29] did not report a significant effect of Tai Chi interventions on social functioning that was reported in other studies, they argued that the control group in their study also had more time for social interaction thus limiting the ability to detect significant differences. Such explanations for the positive effects of Tai Chi suggest that the Tai Chi format should not only focus on the performance of gestures, but also the social supportive aspects. Other explanations for the positive effect of Tai Chi include the potential for Tai Chi, with its requirements for full attention to the exercise, to provide a distraction from cancer-related stress. Such explanations are consistent with the underpinning Taoism philosophy embedded in the practice, with its associated value on contentment, and life self-perception, human self-cultivation. Promoting such values could help promote calmness, relaxation and peace, thereby explaining the positive impacts on QOL.

In terms of effects on the physical domains, studies showed an improvement on physical functioning in those practicing Tai Chi, which is consistent with a qualitative study finding that Tai Chi can improve physical health for older people [51]. Tai Chi requires the coordination of gestures and balance, thereby positively influencing the functioning of the muscular-skeletal and central nervous systems. Tai Chi also focuses on the practice of slow and deep breathing, which increases movement amplitude of the diaphragm, chest and abdomen, thereby potentially improving blood circulation, and strengthening myocardial perfusion [52].

\subsubsection{Upper limb function}

Consistent with Yan et al's [9] systematic review, our results provide moderate level evidence that Tai Chi can improve upper limb function and muscle strength for breast cancer survivors. However, our review included an additional two studies, increasing the sample size for the meta-analysis from 169 to 375 . These additional studies provide insights into effects of longer-term intervention lasting for up to 12 weeks. For breast 
cancer survivors, surgical trauma can cause damage to the tissue in the affected side, which can directly lead to restriction of limb activity or even dysfunction [23]. Tai Chi has unique circular motions, which are performed in a way of being flexible, slow, coherent and stable movements. These motions can greatly enhance limb function by promoting coordination between body muscles and joint activities, especially the upper limb joints[23]. Tai Chi movement may be conducive to the lymphatic return, thereby preventing further tissue damage and upper limb lymph-edema [53].

\subsubsection{Indicators of immune function}

IL-6 is expressed at high levels in the tumor microenvironment during radiotherapy and chemotherapy treatment $[54,55]$, and it has a role in inflammatory regulation and metabolic processes, which is associated with symptoms such as fatigue, and survival in metastatic cancer [55-57]. The current meta-analysis did not identify a reduction in IL-6 levels among breast cancer survivors who used Tai Chi. This finding is inconsistent with Meneses-Echavez et al's [57] meta-analysis, which synthesized the reduction effect of aerobic, resistance training, Tai Chi and Yoga on IL-6 in breast cancer survivors. Interestingly, our study demonstrated a higher level of IL-6 in the Tai Chi group. It has been reported in the literature that IL-6 has a dual effect of proinflammatory and inhibitory inflammation, depending on its source of cell production. IL-6 from adipose tissue can promote tumor cell infiltration and that from T cells can promote tumor cell survival [58], while regular exercise can induce muscle to secrete IL-6 and raise its level to trigger anti-inflammatory effects [59]. While the small sample size of included studies in the current meta-analysis may inhibit a definitive conclusion of the exercise effect of Tai Chi, it is of great interest for future study to explore the origin and effect of IL-6.

Our meta-analysis also showed moderate level evidence that Tai Chi could reduce cortisol levels among cancer survivors. It has been reported that elevated cortisol levels in cancer survivors are associated with suppressed immune function, promoted tumor 
growth and inflammation-related diseases susceptibility [60-61], and also can cause a variety of side effects, including fatigue [30]. Thus, Tai Chi may be helpful for cancer recovery via stabilizing or reducing the cortisol levels.

\subsubsection{Cancer-related fatigue and sleep disorders}

This meta-analysis found moderate level evidence that Tai Chi relieves CRF, which is consistent with Song et al's recent meta-analysis [62]. Aistars [63] proposed physical, psychological and situational aetiologic factors associated with CRF. Tai Chi may have an effect on each of these aetiologic factors. For example, Jin et al. [64] reported that Tai Chi increased the secretion of norepinephrine in the urine, reduce the concentration of salivary cortisol, and make the participants feel more energetic with less fatigue, confusion, anxiety, and other mental disorders. Lu et al. [65] also found that short-term Tai Chi decreased sympathetic modulation and lead to a relaxing state.

The current meta-analysis found low level evidence that Tai Chi is associated with improved sleep, which in turn can reduce fatigue. This finding is consistent with results from a qualitative study, which qualiatively evaluated the effect of Tai Chi on older people [51].

\subsection{Limitations and Implications}

There are several limitations to consider in the interpretation of results of this metaanalysis. First, the majority of included studies were subject to risks of bias and had small sample sizes. Methodological deficits included unclear description of research design, the generation of random sequence, the allocation of hidden and blindness. Although we aimed to evaluate the effect of Tai Chi for cancer survivors, the dominant types of cancer from original studies were breast cancer and lung cancer, which limits the generalizability of results to other cancer types. Second, the interventions included various types of Tai Chi, intervention dose and frequency, as well as the outcome measures used, which impacted on the combined effect of the results. The optimal 
intervention dose for different types of Tai Chi needs further exploration. Further well designed clinical trials with a larger sample size, evaluating different types and doses of Tai Chi interventions are warranted.

Third, the length of intervention and follow-up were short in most included studies, with few long-term effect evaluations. Forth, there were different control groups across included studies, with most being active control groups, including routine rehabilitation training, sham Tai Chi, aerobic exercise, health education, support group, psychological support or cognitive behavioral therapy. Four studies used usual care in the control group, which is arguably treated as an active control. In sensitivity analyses, the removal of study with cognitive behavioral therapy, health education and standard support as the control group resulted in significant improvement in the positive effect of Tai Chi on the social domain of QOL, CRF and sleep.

\section{Conclusion}

The current meta-analysis investigated the effects of Tai Chi on health outcomes of cancer survivors. There is low level evidence suggesting a positive effect of Tai Chi on physical, mental functioning and sleep quality. This meta-analysis further identified moderate levels of evidence of the benefit of Tai Chi for upper limb function and muscle strength in breast cancer survivors. More well-designed trials with larger sample sizes comparing different Tai Chi types and doses are required to determine the most favorable Tai Chi regimens to improve limb function and muscular strength. The current study also identified moderate levels of evidence that Tai Chi could relieve CRF

and reduce cortisol levels. More well designed trials with larger sample sizes, with appropriate focus on social interaction and health education are needed to verify these effects.

\section{Conflict of interest statement}


Funding: This work was supported by the Zhejiang Provincial Natural Science Foundation, LQ17H160014, and China Scholarship Council,201708330161.

Conflict of Interest: No conflict exists: All authors declare that he/she has no conflict of interest.

Share of data: We have full control of all meta-analysis data and we agree to allow the journal to review the data if requested. 
Reference

1. Siegel RL, Miller KD, Jemal A (2018) Cancer statistics, 2018. CA: a cancer journal for clinicians 68(1):7-30

2. Arndt V, Koch-Gallenkamp L, Jansen L, Bertram H, Eberle A, Holleczek B, et al (2017) Quality of life in long-term and very long-term cancer survivors versus population controls in Germany. Acta Oncologica 56(2):190-7

3. Horneber M, Bueschel G, Dennert G, Less D, Ritter E, Zwahlen M (2011) How Many Cancer Patients Use Complementary and Alternative Medicine: A Systematic Review and Metaanalysis. Integrative Cancer Therapies 11(3):187-203

4. Chow TH, Lee BY, Ang ABF, Cheung VYK, Ho MMC, Takemura S (2018) The effect of Chinese martial arts Tai Chi Chuan on prevention of osteoporosis:

A systematic review. Journal of orthopaedic translation 12:74-84

5. Lomas-Vega R, Obrero-Gaitan E, Molina-Ortega FJ, Del-Pino-Casado R ( 2017)Tai Chi for Risk of Falls. A Meta-analysis. Journal of the American Geriatrics Society 65(9):2037-43

6. La Forge R (1997) Mind-body fitness: encouraging prospects for primary and secondary prevention. The Journal of cardiovascular nursing 11(3):53-65

7. Tian YT (2016). Tai ji quan de jian shen zuo yong [Tai Chi Fitness Function]. Sports Time (5):47

8. Wang YL (2012) Yun dong dui ai zheng huan zhe kang fu de yan jiu jin zhan[An update on the effect of exercise on cancer rehabilitation]. NEIJIANG TECHNOLOGY 42(3):75

9. Yan LJ, Cao HJ, Hao YF (2013) Taijiquan gai shan ru xian ai huan zhe sheng cun zhi liang sui ji dui zhao shi yan de xi tong ping jia[Effect of Tai Chi on Quality of Life of Patients with Breast Cancer: A Systematic Review of Randomized Controlled Trials]. Chin J Rehabil Theory Pract (6):592-597

10. Lee MS, Choi T-Y, Ernst E(2010) Tai chi for breast cancer patients: a systematic review. Breast Cancer Research and Treatment 120(2):309-16

11. Pan Y, Yang K, Shi X, Liang H, Zhang F, Lv Q (2015) Tai Chi Chuan Exercise for Patients with Breast Cancer: A Systematic Review and Meta-Analysis. EvidenceBased Complementary and Alternative Medicine 2015:1-15 
12. Zeng Y, Luo T, Xie H, Huang M, Cheng ASK (2014) Health benefits of qigong or tai chi for cancer patients: a systematic review and meta-analyses. Complementary Therapies in Medicine 22(1):173-86

13. Tao WW, Jiang H, Tao XM, Jiang P, Sha LY, Sun XC (2016) Effects of Acupuncture, Tuina, Tai Chi, Qigong, and Traditional Chinese Medicine FiveElement Music Therapy on Symptom Management and Quality of Life for Cancer Patients: A Meta-Analysis. Journal of Pain and Symptom Management 51(4):728-47

14. Yan J, Pan L, Zhang X, Sun C, Cui G (2014) Lack of Efficacy of Tai Chi in Improving Quality of Life in Breast Cancer Survivors: a Systematic Review and Meta-analysis. Asian Pac J Cancer Prev: ASIAN PACIFIC ORGANIZATION CANCER PREVENTION 3715-20

15. Lee MS, Pittler MH, Ernst E (2007) Is Tai Chi an effective adjunct in cancer care? A systematic review of controlled clinical trials. Supportive care in cancer : official journal of the Multinational Association of Supportive Care in Cancer 15(6):597-601

16. Pan YQ, Shi XE, Yao XR, et al (2016) Taijiquan fuzhu kangfu zhiliao ruxianai shuhou buliang fanying de xitong pingjia[Systematic review on effect of Tai Chi Chuan rehabilitative therapy on side effects of postoperative patients with breast cancer]. Journal of Lanzhou University（Medical Sciences) (3):64-72

17. Peter MW, Lee MS, Novakowski J, Osypiuk K, Ligibel J, Carlson LE, et al (2018) Tai Chi and Qigong for cancer-related symptoms and quality of life: a systematic review and meta-analysis. Journal of Cancer Survivorship (2):256-67

18. Li Z, Xu M (2013) Tai Ji yu Jiangshen Qigong de Chayixing Fenxi[Difference analysis between Tai Chi and Health Qigong]. Contemporary Sports Technology (in Chinese) (18):131-2

19. Kron J (2005) Tai Chi and Qi Gong. Journal of Complementary Medicine: CM 4(4):28-9, 32-4, 102

20. Jonathan J. Shuster (2011).Review: Cochrane handbook for systematic reviews for interventions, Version 5.1.0, published 3/2011. Julian P.T. Higgins and Sally Green, Editors.Research Synthesis Methods 2(2): 126-130.

21. Moher D, Liberati A, Tetzlaff J, et al (2009) Preferred reporting items for systematic reviews and meta-analyses: the PRISMA statement. British Medical 
Journal 339 (7716):332

22. Mavridis D, Salanti G (2014) How to assess publication bias: funnel plot, trimand-fill method and selection models. Evidence Based Mental Health 17(1):30

23. Li YQ, Li LL, Wei W (2013) Tai ji yun shou dui ru xian ai shu hou huan zhe zhi ti gong neng kang fu de ying xiang [Effect of Taiji Cloud Hand on Rehabilitation of Limb Function for Breast Cancer Patient]. Fujian Journal of TCM(in Chinese) 5:57-8

24. Sun QY, Tang LL, Zhou LH, et al ( 2012) Zong he kang fu duan lian dui ru xian ai di yi qi ru fang chong jian shu hou shang zhi gong neng kang fu he sheng huo zhi liang de ying xiang [Effect of Comprehensive Rehabilitation Exercise on Rehabilitation and Quality of Life of Upper Limbs in Breast Cancer Stage I Mast Reconstruction]. Chin J Phys Med Rehabil (4):302-5

25. Wang YL, Sun QY, Wang YB ( 2012) Butong yundong fangshi dui ruxianai shuhou huanzhe shangzhi gongneng ji shenghuo zhiliang de yingxiang [Effects of Different Exercise Modes on Upper Limb Function and Quality of Life in Postoperative Patients with Breast Cancer[Chin J Phys Med Rehabil (1):64-6

26. Wang HY, Dai SJ, Hu M (2016) Tai ji quan yun dong dui ru xian ai shu hou huan zhe jian guan jie gong neng he sheng ming zhi liang de ying xiang [Effects of Taijiquan on Shoulder Function and Quality of Life for Breast Cancer Patients after Surgery]. Journal of New Medicine 26(3):231-3

27. Xiao H, Feng T, Duan YL, et al (2013) Butong kangfu duan lian fa dui laonian ruxianai huanzhe shuhou shenguo zhiliang ji shangzhi gongneng de yingxiang [Effects of Different Rehabilitation Exercises on Quality of Life and Upper Limb Function in Elderly Patients with Breast Cance] Chinese Journal of Gerontology (2):420-1

28. Lv F, Yu Y, Liang D, et al (2015) Ba duan jin ji tai ji quan duan lian dui ru xian ai shu hou sheng huo zhi liang de ying xiang [Effect of Baduanjin Exercise and Shadowboxing on Quality of Postoperation Life for Breast Cancer Patient. Journal of Wuhan Institute Physical Education (7):80-3

29. Campo RA, O'connor K, Light KC, Nakamura Y, Lipschitz DL, Lastayo PC, et al (2013) Feasibility and Acceptability of a Tai Chi Chih Randomized Controlled Trial in Senior Female Cancer Survivors. Integrative Cancer Therapies 12(6):464-74

30. Sprod LK, Janelsins MC, Palesh OG, Carroll JK, Heckler CE, Peppone LJ, et al 
(2012) Health-related quality of life and biomarkers in breast cancer survivors participating in tai chi chuan. J Cancer Surviv 6(2):146-54

31. Larkey LK, Roe DJ, Smith L, Millstine D (2016) Exploratory outcome assessment of Qigong/Tai Chi Easy on breast cancer survivors. Complement Ther Med 29:196-203

32. Mustian K, Katula J, Gill D, Roscoe J, Lang D, Murphy K (2004) Tai Chi Chuan, health-related quality of life and self-esteem: A randomized trial with breast cancer survivors. Supportive Care in Cancer 12(12):871-6

33. Mustian KM, Katula JA, Zhao H (2006) A pilot study to assess the influence of tai chi chuan on functional capacity among breast cancer survivors. J Support Oncol 4(3):139-45

34. Mustian KM, Palesh OG, Flecksteiner SA (2008) Tai Chi Chuan for breast cancer survivors. Med Sport Sci 52:209-17

35. Janelsins MC, Davis PG, Wideman L, Katula JA, Sprod LK, Peppone LJ, et al (2011) Effects of Tai Chi Chuan on insulin and cytokine levels in a randomized controlled pilot study on breast cancer survivors. Clin Breast Cancer 11(3):161-70

36. Campo RA, Light KC, O'Connor K, Nakamura Y, Lipschitz D, LaStayo PC, et al (2015) Blood pressure, salivary cortisol, and inflammatory cytokine outcomes in senior female cancer survivors enrolled in a tai chi chih randomized controlled trial. $\mathrm{J}$ Cancer Surviv 9(1):115-25

37. Jiang MY, Wang M, Song CA (2013) Tai ji quan dui gai shan wan qi fei ai bing ren ai yin xing pi fa ji shui mian zhi liang de ying xiang [Influence of Shadowboxing on Improving Cancer-related Fatigue and Sleeping Quality of Patients with advanced Lung Cancer]. Chinese Nursing Research (2):420-1

38. Larkey LK, Roe DJ, Weihs KL, Jahnke R, Lopez AM, Rogers CE, et al (2015) Randomized controlled trial of Qigong/Tai Chi Easy on cancer-related fatigue in breast cancer survivors. Ann Behav Med 49(2):165-76.

39. Irwin MR, Olmstead R, Carrillo C, Sadeghi N, Nicassio P, Ganz PA, et al (2017) Tai Chi Chih Compared With Cognitive Behavioral Therapy for the Treatment of Insomnia in Survivors of Breast Cancer: A Randomized, Partially Blinded, Noninferiority Trial. Journal of clinical oncology : official journal of the American Society of Clinical Oncology 35(23):2656-65 
40. Fan Y. (2014) Shu hou kang fu yun dong dui fen hua xing fei ai nei fen mi xi tong tiao jie ying xiang [Influence of Endocrine System Regulating Efect on Diferentiation Lung Cancer Under Postoperative Rehabilitation Exercise]. BULLETIN OF SCIENCE AND TECHNOLOGY (10):25-7

41. Peppone LJ, Mustian KM, Janelsins MC, Palesh OG, Rosier RN, Piazza KM, et al (2010) Effects of a Structured Weight-Bearing Exercise Program on Bone Metabolism Among Breast Cancer Survivors: A Feasibility Trial. Clinical Breast Cancer 10(3):224-9

42. Wang R, Liu J, Chen P, Yu D (2013) Regular tai chi exercise decreases the percentage of type 2 cytokine-producing cells in postsurgical non-small cell lung cancer survivors. Cancer nursing 36(4):E27-34

43. Liu J, Chen P, Wang R, Yuan Y, Wang X, Li C (2015) Effect of Tai Chi on mononuclear cell functions in patients with non-small cell lung cancer. BMC Complement Altern Med 15:3

44. Zhang YJ, Wang R, Chen PJ, Yu DH (2013) Effects of Tai Chi Chuan training on cellular immunity in post-surgical non-small cell lung cancer survivors: A randomized pilot trial. Journal of Sport and Health Science 2(2):104-8

45. YuGong LT, Qiao YL (Editor). Yuan ZL, Chen YK (Translator) (2016) Ri ben zhuan jia tai ji quan yan jiu xi lie tai ji quan zhi bing zhi ao mi[Japanese Expert Tai Chi Research Series Taiji Fist Treatment Mystery]. Beijing: People's Sports Press.

46. Zheng Y,Ma YJ, Kongzi TY, Yi XM (2012) Hu nan sheng chen shi yu yang shi tai ji quan fa zhan dui bi yan jiu: ji yu hu nan sheng di er jie tai ji quan jin biao sai de diao cha [Comparative Study of Chen-style Taijiquan and Yangstyle Taijiquan in Hu'nan]. WUSHU SCIENCE (4):39-40

47. Fallowfield L (2002) Quality of life: a new perspective for cancer patients. Nat Rev Cancer 2(11):873-9

48. You J (2006) Yan zhi zhong liu huan zhe sheng huo liang biao zhong yi ban de yi yi ji bi yao xing[Significance and necessity of developing quality of life questionnaire for cancer patients adapting to traditional Chinese medicine]. JOURNAL OF CHINESE INTEGRATIVE MEDCINES (5):473-7

49. Jacobsen PB, Jim HS.(2011) Consideration of quality of life in cancer survivorship research. Cancer Epidemiol Biomarkers Prev 20(10):2035-41 
50. Li Y, Tao R, Chen HF, Zhang L, Hu J (2017) Tai ji quan yun dong dui ti gao lao nian ren sheng huo zhi liang de zuo yong he yi yi[The Effect and Significance of Tai Chi Exercise on Improving Senior Citizens' Quality of Life]. Chinese Journal of Integrative Medicine on Cardiovascular Disease (4):95,98

51. Zheng G, Xiong Z, Zheng X, et al(2017)Subjective perceived impact of Tai Chi training on physical and mental health among community older adults at risk for ischemic stroke: a qualitative study. BMC Complement Altern Med17(1):221

52. WuShi LT, Gao YF (2017) Tai ji quan duan lian dui ai zheng huan zhe xiao guo de guo wai yan jiu xia zhuang [The Current Situation of Overseas Research on the Effect of Taijiquan Exercise on Cancer Patients]. Martial Arts Research (4):62-4

53. Wang YL, Sun XY, Wang LH, Fang HX, Liu LN (2010) Tai ji quan yun dong dui ru xian ai huan zhe shu hou huan zhi gong neng ji sheng huo zhi liang de yin xiang[Effect of Taijiquan Exercise on the Recovery of Limb Function and the Quality of Life after Surgery of Breast Cancer Patients]. CHINA SPORT SCIENCE AND TECHNOLOGY (5):125-8

54. Walter M, Liang S, Ghosh S, Hornsby PJ, Li R (2009) Interleukin 6 secreted from adipose stromal cells promotes migration and invasion of breast cancer cells. Oncogene 28(30):2745-55

55. Lin YR ( 2018) Fei ai huan zhe ai yin xing pi fa yu xue qing $C$ fan ying dan bai bai jie 6、shen shang xian pi zhi ji su v pi zhi chun de guan xi yan jiu [Stduy on the Relatioship between Cation-related Fatigue and Serum CPR, IL-6, ATCH, Cortisol in Patients with Lung Cancer]. Journal of Clinical Pulmonary 23(1):146-9

56. Zhang X, Zheng D, Ma YH (2015) Bai ji 6 zai dai xie lei ji bing ji ai zheng zhong de gong neng yan jiu jin zhan[Advances in the Research of IL-6 Function in Metabolic and Cancer. Progress in Biotechnology (5):347-50

57. Meneses-Echavez JF, Correa-Bautista JE, Gonzalez-Jimenez E, Schmidt Rio-Valle J, Elkins MR, Lobelo F, et al (2016) The Effect of Exercise Training on Mediators of Inflammation in Breast Cancer Survivors: A Systematic Review with Meta-analysis. Cancer Epidemiol Biomarkers Prev 25(7):1009-17

58. Pedersen BK, Steensberg A, Fischer C, et al( 2004)The metabolic role of IL-6 produced during exercise: is IL-6 an exercise factor? Proc Nutr Soc63(2):263-7

59. Petersen AM, Pedersen BK(2006) The role of IL-6 in mediating the anti- 
inflammatory effects of exercise. J Physiol Pharmacol 57 Suppl 10:43-51

60. Rozell TG, Murphy B, de Avila DM, Banks KL, Reeves JJ (1992) Antibodies against cortisol block suppressive effects of corticosteroids on lymphocytes in vitro. Proc Soc Exp Biol Med 199(4):404-9

61. Liu RZ, Hou YC, Li L, Liu XC, Zhao XJ, Meng QR, Zhang J, Yang F (1999)

Xiao hua xi tong zhong liu huan zhe xue jiang gao tong pi zhi chun han liang he $\mathrm{T}$ lin ba xi bao gong neng de bian hua[Changes of $\mathrm{T}$ lymphocytes function and contents of corticosteroids and testosterone of patients with cancer of digestive system]. CHINESE JOURNAL OF PATHOPHYSIOLOGY (2):134-6

62. Song S, Yu J, Ruan Y, Liu X, Xiu L, Yue X (2018) Ameliorative effects of Tai Chi on cancer-related fatigue: a meta-analysis of randomized controlled trials. Supportive Care in Cancer 26(7):2091-102

63. Aistars J(1987). Fatigue in the cancer patient: A conceptual approach to a clinical problem. Oncol Nurs Forum14(6):25-30.

64. Jin P (1989) Changes in heart rate, noradrenaline, cortisol and mood during Tai Chi. Journal of psychosomatic research 33(2):197-206

65. Lu WA, Kuo CD.(2003) The effect of Tai Chi Chuan on the autonomic nervous modulation in older persons. Medicine and science in sports and exercise 35(12):1972-6 
Fig.1 PRISMA Flowchart

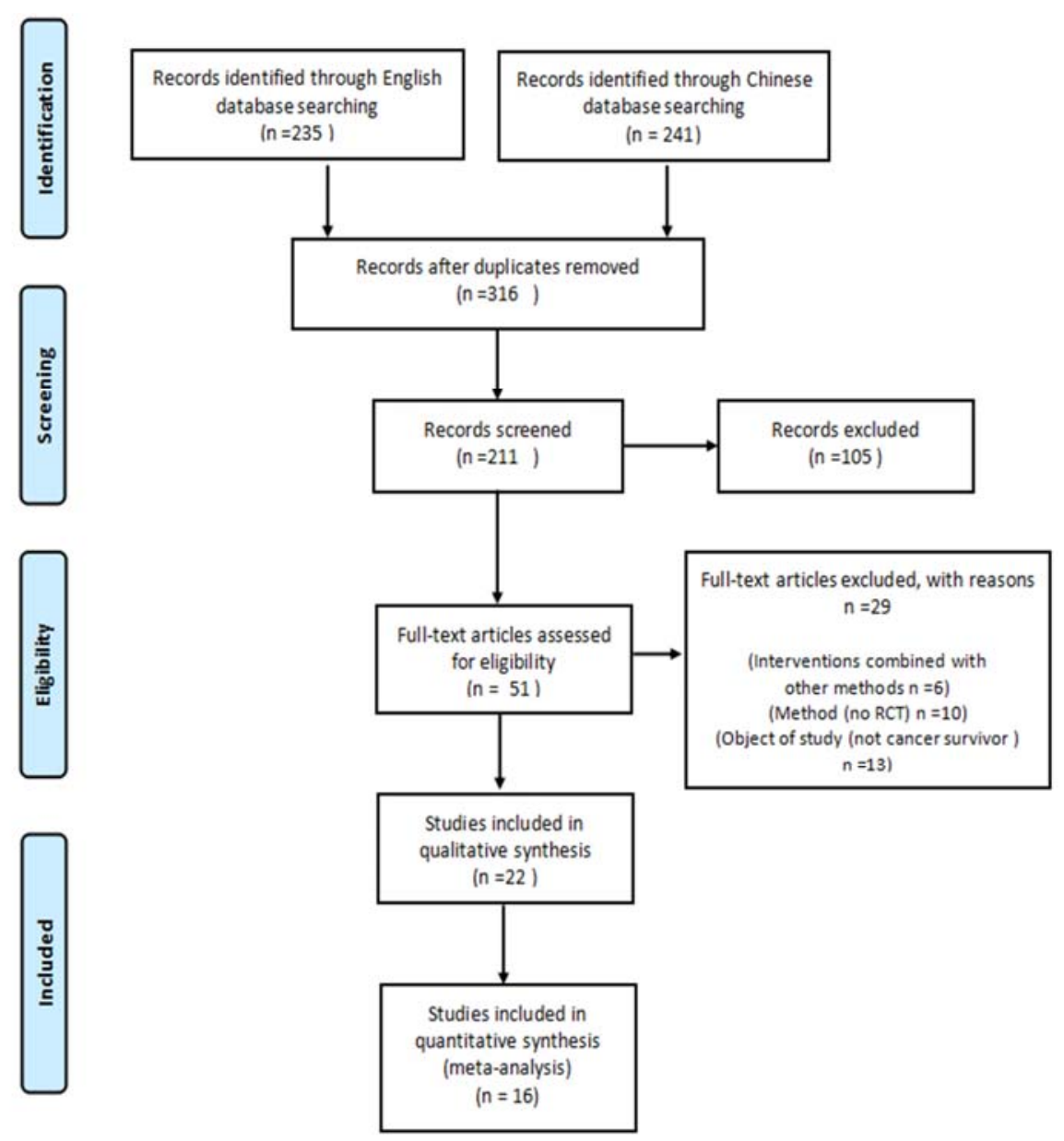


Table 1 Characteristics of the included studies

\begin{tabular}{|c|c|c|c|c|c|c|}
\hline \multirow{2}{*}{$\begin{array}{c}\text { Authors/year/co } \\
\text { untry }\end{array}$} & \multirow{2}{*}{$\begin{array}{c}\text { Cancer } \\
\text { Type }\end{array}$} & \multirow[t]{2}{*}{ Current Status } & \multicolumn{2}{|l|}{ Arms } & \multirow{2}{*}{ 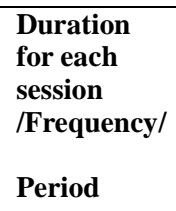 } & \multirow[t]{2}{*}{ Outcome measures/results } \\
\hline & & & $\begin{array}{l}\text { Intervention group } \\
\text { (Number /age ) }\end{array}$ & $\begin{array}{l}\text { Control group } \\
\text { (Number /age ) }\end{array}$ & & \\
\hline $\begin{array}{l}\text { Li YQ et al, } \\
\text { 2013,China[23] }\end{array}$ & $\begin{array}{l}\text { Breast } \\
\text { Cancer }\end{array}$ & $\begin{array}{l}\text { After modified } \\
\text { radical } \\
\text { mastectomy }\end{array}$ & $\begin{array}{l}\text { Taiji cloud hand( three nurses } \\
\text { instructed by a Tai chi expert) } \\
\mathrm{N}=29 \quad(29 \sim 68)\end{array}$ & $\begin{array}{l}\text { Routine rehabilitation } \\
\text { training } \\
\mathrm{N}=28 \quad(29 \sim 68)\end{array}$ & $\begin{array}{l}20-30 \min ; 3 \\
\text { times/ day; } \\
6 \text { months }\end{array}$ & $\begin{array}{l}\text { Significant improvements in Muscle strength (Lovett } \\
\text { grading method) }(\mathrm{P}<0.01) \text { and QOL (WHOQOLBREF) } \\
(\mathrm{P}<0.05)\end{array}$ \\
\hline $\begin{array}{l}\text { Sun XY et al, } \\
\text { 2012,China[24] }\end{array}$ & $\begin{array}{l}\text { Breast } \\
\text { Cancer }\end{array}$ & $\begin{array}{l}\text { After extended } \\
\text { latissimus dorsi } \\
\text { Flap and } \\
\text { Reconstruction } \\
\text { of stage I after } \\
\text { modified radical } \\
\text { mastectomy for } \\
\text { breast cancer }\end{array}$ & $\begin{array}{l}\text { 24-Form Yang Tai chi touch by } \\
\text { Professional coach } \\
\mathrm{N}=41 \quad 39.18(28 \sim 53)\end{array}$ & $\begin{array}{l}\begin{array}{l}\text { Routine rehabilitation } \\
\text { training/Fitness yang dance } \\
\text { exercise }\end{array} \\
\mathrm{N}=42 / 35 \quad 39.18(28 \sim 53)\end{array}$ & $\begin{array}{l}20 \min ; 2 \\
\text { times/day; } 6 \\
\text { months }\end{array}$ & $\begin{array}{l}\text { Significant improvements in shoulder function } \\
\text { (Constant-Murley shoulder function evaluation } \\
\text { standard) }(\mathrm{P}<0.05) \text { and Subjective Feeling with Quality of } \\
\text { Life,Subjective Feeling with Health,Physiological, } \\
\text { Psychological and Social Relationship of } \\
\text { QOL(WHOQOL-BBEF ) }(\mathrm{P}<0.05)\end{array}$ \\
\hline $\begin{array}{l}\text { Wang YL et al, } \\
\text { 2012, China[25] }\end{array}$ & $\begin{array}{l}\text { Breast } \\
\text { Cancer }\end{array}$ & $\begin{array}{l}\text { After modified } \\
\text { radical cure } \\
\text { surgery }\end{array}$ & $\begin{array}{l}\text { 24-Form Yang Tai chi } \\
\mathrm{N}=63 \quad(28 \sim 65)\end{array}$ & $\begin{array}{l}\text { Yangge dance/Routine } \\
\text { rehabilitation training } \\
\mathrm{N}=51 / 71 \quad(28 \sim 65)\end{array}$ & $\begin{array}{l}20 \mathrm{~min} ; 2 \\
\text { times/day, } \\
6 \text { months }\end{array}$ & $\begin{array}{l}\text { Significant improvements in shoulder function } \\
\text { (Constant-Murley shoulder function evaluation } \\
\text { standard)(P<0.05) and Subjective Feeling with Quality of } \\
\text { Life , Subjective Feeling with Health, Physiological, } \\
\text { Psychological and Social Relationship of QOL } \\
\text { (WHOQOL-BBEF ) }(\mathrm{P}<0.05)\end{array}$ \\
\hline $\begin{array}{l}\text { Wang HY et al, } \\
2016 \text { China[26] }\end{array}$ & $\begin{array}{l}\text { Breast } \\
\text { Cancer }\end{array}$ & $\begin{array}{l}\text { After modified } \\
\text { radical } \\
\text { mastectomy }\end{array}$ & $\begin{array}{l}\text { Taijiquan( taught by Tai chi coach and } \\
\text { patrol supervisor nurse on time) } \\
\mathrm{N}=48 \quad(53.64 \pm 7.1)\end{array}$ & $\begin{array}{l}\text { Routine rehabilitation } \\
\text { training } \\
\mathrm{N}=48 \quad(51.74 \pm 7.67)\end{array}$ & $\begin{array}{l}20-30 \min ; 2 \\
\text { times/ day; } \\
3 \text { months }\end{array}$ & $\begin{array}{l}\text { Significant improvements in shoulder function (Neer } \\
\text { shoulder function scoring system) }(\mathrm{P}<0 \text {. 05) and Physica } \\
\text { Well-being, Emotional Well-being, Functional } \\
\text { Well-being, Additional Concerns of QOL(FACT-B ) } \\
(\mathrm{P}<0.05)\end{array}$ \\
\hline
\end{tabular}




\begin{tabular}{|c|c|c|c|c|c|c|}
\hline \multirow[t]{2}{*}{$\begin{array}{l}\text { Xiao H et al, } \\
\text { 2013, China[27] }\end{array}$} & \multirow[t]{2}{*}{$\begin{array}{l}\text { Breast } \\
\text { Cancer }\end{array}$} & \multirow[t]{2}{*}{$\begin{array}{l}\text { After unilateral } \\
\text { breast cancer } \\
\text { modified radical } \\
\text { surgery }\end{array}$} & \multirow[t]{2}{*}{$\begin{array}{l}\text { 24-Form Yang Tai chi } \\
\mathrm{N}=33 \quad(70.5 \pm 4.2)\end{array}$} & $\begin{array}{l}\text { Aerobic exercises (Arm } \\
\text { walking preparation } \\
\text { activities,the limb help } \\
\text { movement, Neck assisted } \\
\text { movement,Chest movement, } \\
\text { Joint movement, the arm } \\
\text { shake activity ) }\end{array}$ & \multirow[t]{2}{*}{$\begin{array}{l}20 \mathrm{~min} ; 2 \\
\text { times/day, } \\
6 \text { months }\end{array}$} & \multirow[t]{2}{*}{$\begin{array}{l}\text { Significant improvements in shoulder function (Neer } \\
\text { shoulder function scoring system })(\mathrm{P}<0.05) \text { and } \\
\text { Social/Family Well-being,Emotional Well-being, } \\
\text { Functional Well-being, Additional Concerns of } \\
\text { QOL(FACT-B ) }(\mathrm{P}<0.05)\end{array}$} \\
\hline & & & & $\mathrm{N}=33 \quad(70.3 \pm 3.6)$ & & \\
\hline $\begin{array}{l}\text { Lv F et al , 2015, } \\
\text { China[28] }\end{array}$ & $\begin{array}{l}\text { Breast } \\
\text { Cancer }\end{array}$ & $\begin{array}{l}\text { After unilateral } \\
\text { breast cancer } \\
\text { modified radical } \\
\text { surgery, } \\
\text { undergone } \\
\text { surgery, } \\
\text { chemotherapy } \\
\text { therapy }\end{array}$ & $\begin{array}{l}\text { 24-Form Yang Tai chi (the State Sports } \\
\text { General Administration by tai chi coach } \\
\text { to conduct live teaching and play tai chi } \\
\text { video) } \\
\mathrm{N}=50 \quad 48.61(32-65)\end{array}$ & $\begin{array}{l}\text { Ba Duan Jin/Routine } \\
\text { rehabilitation training } \\
\mathrm{N}=50 / 49 \quad 48.61(32-65)\end{array}$ & $\begin{array}{l}\text { Over } \\
60 \mathrm{~min} ; 3 \\
\text { times/week; } \\
6 \text { months }\end{array}$ & $\begin{array}{l}\text { Significant improvements in upper limb } \\
\text { function(Constant-Murley shoulder function } \\
\text { measurement standard) }(\mathrm{P}<0 \text {. 05) and RP, SF, RE, Vt, } \\
\text { MH QOL(SF-36) }\end{array}$ \\
\hline $\begin{array}{l}\text { Campo et al, } \\
\text { 2013,USA[29] }\end{array}$ & $\begin{array}{l}\text { Female } \\
\text { cancer } \\
\text { patients }\end{array}$ & $\begin{array}{l}\geq 3 \text { months since } \\
\text { completing } \\
\text { treatment } \\
\text { (exception of } \\
\text { hormone } \\
\text { therapy), with no } \\
\text { detectable cancer }\end{array}$ & $\begin{array}{l}\text { Tai Chi Chih Movements ( } 20 \text { minute } \\
\text { warm-up, } 30 \text { minutes of Tai Ji with } 19 \\
\text { movements and one standing pose and } \\
10 \text { minutes of closing movements) } \\
\mathrm{N}=29 \quad(67 \pm 7.15)\end{array}$ & $\begin{array}{l}\text { Health Education (topics } \\
\text { relevant to successful } \\
\text { aging, pain, nutrition, sleep } \\
\text { changes, social roles \& } \\
\text { relationships), with the } \\
\text { majority of topics spanning } \\
\text { two classes by a variety of } \\
\text { health specialists } \\
\mathrm{N}=25 \quad(67 \pm 7.15)\end{array}$ & $\begin{array}{l}60 \mathrm{~min} \\
\text { three times/ } \\
\text { week; } \\
\text { 12-week } \\
\text { period }\end{array}$ & $\begin{array}{l}\text { Significant improvements in the mental component } \\
\text { summary score in TCC }(\text { SF-36v1) }(p=0.01) \text {, but not in } \\
\text { HEC }\end{array}$ \\
\hline $\begin{array}{l}\text { Sprod et al, } \\
\text { 2012,USA[30] }\end{array}$ & $\begin{array}{l}\text { Breast } \\
\text { Cancer }\end{array}$ & $\begin{array}{l}\text { Treatment } \\
\text { completed more } \\
\text { than } 1 \text { month } \\
\text { prior but less } \\
\text { than } 30 \text { months } \\
\quad \text { prior }\end{array}$ & $\begin{array}{l}\text { 24-Form Yang Tai chi (10-min } \\
\text { warm-up, } 40 \text { min of Yang-style tai chi } \\
\text { chuan using the } 15 \text {-move short form } \\
\text { and } 10 \text { min of guided breathing) } \\
\mathrm{N}=11\end{array}$ & $\begin{array}{l}\text { Standard support } \\
\text { therapy control ( emphasis on } \\
\text { behavioral coping skills, } \\
\text { group cohesion, and peer } \\
\text { support) } \\
\mathrm{N}=10 \quad(52.70 \pm 2.11)\end{array}$ & $\begin{array}{l}60 \mathrm{~min} ; 3 \\
\text { times/ week; } \\
12 \text { weeks }\end{array}$ & $\begin{array}{l}\text { The TCC group improved in total HRQOL }(\mathrm{T} 1-\mathrm{T} 2 \text { : } \\
\mathrm{CS}=8.54, \mathrm{P}=0.045) \text {, physical functioning }(\mathrm{T} 1- \\
\mathrm{T} 2: \mathrm{CS}=1.89, \mathrm{P}=0.030) \text {, physical role limitations }(\mathrm{T} 1-\mathrm{T} 2 \\
\mathrm{CS}=1.55, \mathrm{P}=0.023) \text {, social functioning }(\mathrm{T} 1-\mathrm{T} 3: \mathrm{CS}=1.50 \text {, } \\
\mathrm{P}=0.020) \text {, and general mental health }(\mathrm{T} 1-\mathrm{T} 2: \mathrm{CS}=2.67 \text {, } \\
\mathrm{P}=0.014 ; \mathrm{T} 1-\mathrm{T} 3: \mathrm{CS}=2.44, \mathrm{P}=0.019) \text {. Cortisol changes } \\
\text { were associated with changes in physical role limitations } \\
(\mathrm{r}=0.74 ; \mathrm{P}<0.05) \text { and health perceptions }(\mathrm{r}=0.46 ; \mathrm{P}<0.05) \text {. }\end{array}$ \\
\hline
\end{tabular}




\begin{tabular}{|c|c|c|c|c|c|c|}
\hline $\begin{array}{l}\text { Larkey et al, } \\
\text { 2016, USA[31] }\end{array}$ & $\begin{array}{l}\text { Breast } \\
\text { Cancer }\end{array}$ & $\begin{array}{l}\text { Six monthsto } 5 \\
\text { years past } \\
\text { primary } \\
\text { treatment } \\
\text { (including } \\
\text { surgery, } \\
\text { radiation,or } \\
\text { chemotherapy) }\end{array}$ & $\begin{array}{l}10 \text { QG/TCE exercises based on Tai Chi } \\
\text { Easy } \\
\mathrm{N}=42 \quad(57.7 \pm 8.94)\end{array}$ & $\begin{array}{l}\text { Sham Qigong (i.e., similar } \\
\text { movements as QG/TCE } \\
\text { without the meditative focus) } \\
\mathrm{N}=45 \quad(59.8 \pm 8.93)\end{array}$ & $\begin{array}{l}\text { at least } 30 \\
\text { min;5 days/ } \\
\text { week; } 12 \\
\text { weeks }\end{array}$ & $\begin{array}{l}\text { Both groups demonstrated pre-to-post-intervention } \\
\text { improvements in physical and mentalhealth, level of } \\
\text { PA(SF-), self-reported cognitive function, and cognitive } \\
\text { performance tests (FACT-COG), though without } \\
\text { significant differences between QG/TCE and SQG. }\end{array}$ \\
\hline $\begin{array}{l}\text { Mustian et al, } \\
2004 \text {, USA[32] }\end{array}$ & $\begin{array}{l}\text { Breast } \\
\text { Cancer }\end{array}$ & $\begin{array}{l}1 \text { week and } 30 \\
\text { months after } \\
\text { treatment }\end{array}$ & $\begin{array}{l}\text { 24-Form Yang Tai chi (10 minutes of } \\
\text { warm-up stretching and basic Chi } \\
\text { Kung } i \text { a } 15 \text {-move short form of } \\
\text { Yang-style) } \\
\mathrm{N}=11 \quad 52 \pm 9(33 \sim 78)\end{array}$ & $\begin{array}{l}\text { Psychological support } \\
\text { (teaching behavioral coping } \\
\text { strategies, peer support, and } \\
\text { group cohesion by a graduate } \\
\text { exercise psychology student) } \\
\mathrm{N}=10 \quad 52 \pm 9(33 \sim 78)\end{array}$ & $\begin{array}{l}60 \mathrm{~min} ; 3 \\
\text { times/ week; } \\
12 \text { weeks }\end{array}$ & $\begin{array}{l}\text { Significant improvements in HRQL(FACIT-F) } \\
(\mathrm{P}<0.05) \text { and self-esteem, while }(\mathrm{RSE})(\mathrm{P}<0.05) \text { the PST } \\
\text { group reported declines in HRQL and self-esteem }\end{array}$ \\
\hline $\begin{array}{l}\text { Mustian et al, } \\
2006 \text {,USA[33] }\end{array}$ & $\begin{array}{l}\text { Breast } \\
\text { Cancer }\end{array}$ & $\begin{array}{l}1 \text { week and } 30 \\
\text { months post } \\
\text { treatment }\end{array}$ & $\begin{array}{l}\text { 24-Form Yang Tai chi }(10 \text { minutes of } \\
\text { warm-up stretching and basic Chi } \\
\text { Kung;a } 15 \text {-move short form of } \\
\text { Yang-style) } \\
\mathrm{N}=11 \quad 52 \pm 9(33 \sim 78)\end{array}$ & $\begin{array}{l}\text { Psychological therapy } \\
\text { (teaching behavioral coping } \\
\text { strategies, peer support, and } \\
\text { group cohesion by a trained } \\
\text { counselor and an exercise } \\
\text { psychology graduate student) } \\
\mathrm{N}=10 \quad 52 \pm 9\left(\begin{array}{ll}33 \sim 78)\end{array}\right.\end{array}$ & $\begin{array}{l}60 \mathrm{~min} ; 3 \\
\text { times/ week; } \\
12 \text { weeks }\end{array}$ & $\begin{array}{l}\text { The TCC group demonstrated significant improvement } \\
\text { in functional capacity (specifically aerobic capacity, } \\
\text { muscular strength, and flexibility) whereas the PST group } \\
\text { showed significant improvement in flexibility only. }\end{array}$ \\
\hline $\begin{array}{l}\text { Mustian et al } \\
2008 \text {, USA[34] }\end{array}$ & $\begin{array}{l}\text { Breast } \\
\text { Cancer }\end{array}$ & $\begin{array}{l}\text { Between } 1 \\
\text { week and } 30 \\
\text { months after } \\
\text { treatment }\end{array}$ & $\begin{array}{l}\text { 24-Form Yang Tai chi }(10 \text { minutes of } \\
\text { warm-up stretching and basic Chi } \\
\text { Kung; a 15-move short form of } \\
\text { Yang-style) } \\
\mathrm{N}=11 \quad 52 \pm 9(33 \sim 78)\end{array}$ & $\begin{array}{l}\text { Psychological therapy } \\
\text { (teaching behavioral coping } \\
\text { strategies, peer support, and } \\
\text { group cohesion by a trained } \\
\text { counselor and an Exercise } \\
\text { Psychology graduate student) } \\
\mathrm{N}=10 \quad 52 \pm 9\left(\begin{array}{ll}33 & \sim 78\end{array}\right)\end{array}$ & $\begin{array}{l}60 \mathrm{~min} ; 3 \\
\text { times/ week; } \\
12 \text { weeks }\end{array}$ & $\begin{array}{l}\text { Significant improvements in functional capacity,including } \\
\text { aerobic capacity, muscular strength, and flexibility, as } \\
\text { well as QOL }((\text { FACIT-F) }(\mathrm{P}<0 . .5)\end{array}$ \\
\hline
\end{tabular}




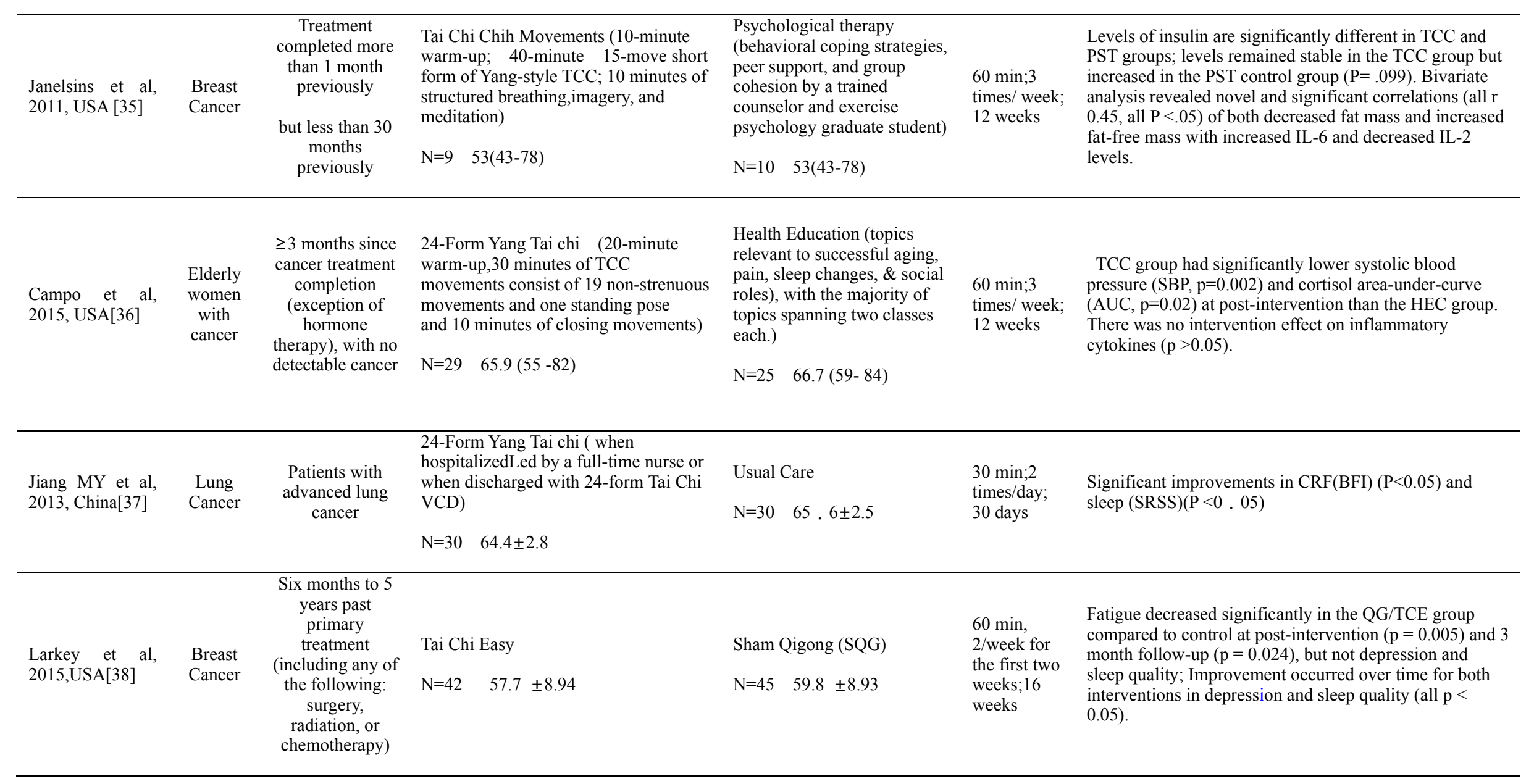




\begin{tabular}{|c|c|c|c|c|c|c|}
\hline $\begin{array}{l}\text { Irwin, MR. et al, } \\
\text { 2017, USA[39] }\end{array}$ & $\begin{array}{l}\text { Breast } \\
\text { Cancer }\end{array}$ & $\begin{array}{l}\geq 6 \text { months since } \\
\text { cancer treatment } \\
\text { completion(surge } \\
\text { ry, radiation, } \\
\text { and/or } \\
\text { chemotherapy ) }\end{array}$ & $\begin{array}{l}\text { TCC } \\
\mathrm{N}=45\end{array}$ & $\begin{array}{l}\text { CBT } \\
\mathrm{N}=45 \quad 60.0 \pm 9.3\end{array}$ & $\begin{array}{l}\text { weekly } \\
120 \text {-minute } \\
\text { sessions }\end{array}$ & $\begin{array}{l}\text { Tests of noninferiority showed that TCC was noninferior } \\
\text { to CBT-I at } 3 \text { months }(\mathrm{P}=.02) \text {. Between-group } \\
\text { differences in change of fatigue from baseline to } 3 \\
\text { months were not significant. }\end{array}$ \\
\hline \multirow{2}{*}{$\begin{array}{l}\text { Fan Y et al, } \\
2014 \text {, China[40] }\end{array}$} & \multirow{2}{*}{$\begin{array}{l}\text { Lung } \\
\text { Cancer }\end{array}$} & \multirow{2}{*}{$\begin{array}{l}\text { After lung cancer } \\
\text { surgery }\end{array}$} & Tai Chi & $\begin{array}{l}\text { Walking/yoga/rehabilitation } \\
\text { gymnastics }\end{array}$ & \multirow{2}{*}{$\begin{array}{l}60 \text { min; } \\
\text { every day } \\
8 \text { weeks }\end{array}$} & \multirow{2}{*}{$\begin{array}{l}\text { Significant improvements in Carcinogenin } \\
\text { secretion and rehabilitation index }\end{array}$} \\
\hline & & & $\mathrm{N}=22 \quad 55 \quad(43-75)$ & $25 / 29 / 31 \quad 55 \quad(43-75)$ & & \\
\hline \multirow[t]{2}{*}{$\begin{array}{l}\text { Peppone et al, } \\
2010 \text {, USA[41] }\end{array}$} & \multirow[t]{2}{*}{$\begin{array}{l}\text { Breast } \\
\text { Cancer }\end{array}$} & \multirow[t]{2}{*}{$\begin{array}{l}\text { Treatment } \\
\text { completed more } \\
\text { than } 1 \text { month } \\
\text { previously, but } \\
\text { less than } 30 \\
\text { months before } \\
\text { enrollment }\end{array}$} & $\begin{array}{l}\text { 24-Form Yang Tai chi ( } 10 \text { minutes } \\
\text { warm-up exercises, stretches, and Chi } \\
\text { Kung; } 40 \text { min } 15 \text {-move short form of } \\
\text { Yang-style; } 10 \text { minutes of regulatory } \\
\text { breathing) }\end{array}$ & $\begin{array}{l}\text { Standard support therapy } \\
\text { ( behavioral coping } \\
\text { strategies, cohort support, } \\
\text { and group Unity by a trained } \\
\text { counselor and exercise } \\
\text { psychology graduate student ) }\end{array}$ & \multirow[t]{2}{*}{$\begin{array}{l}60 \mathrm{~min}, 3 \\
\text { times / } \\
\text { week ;12 } \\
\text { weeks }\end{array}$} & \multirow[t]{2}{*}{$\begin{array}{l}\text { TCC group experienced a greater increase in levels of } \\
\text { bone formation (BSAP }[\mu \mathrm{g} / \mathrm{L}] \text { : before, } 8.3 \text {; after, } 10.2 \text {; } \\
\text { change, } 1.9 \mu \mathrm{g} / \mathrm{L} \text { and } 22.4 \% \text { ) and in bone resorption(NTx } \\
\text { [nanomoles bone collagen equivalent; nmBCE]: before, } \\
\text { 17.6; after, } 11.1 \text {; change, }-6.5 \mathrm{nmBCE} ;-36.9 \% \text { ) }\end{array}$} \\
\hline & & & $\mathrm{N}=7 \quad 53.8(43-78)$ & $\mathrm{N}=9 \quad 52.6(43-78)$ & & \\
\hline \multirow{2}{*}{$\begin{array}{l}\text { Wang et al, 2013, } \\
\text { China[42] }\end{array}$} & \multirow{2}{*}{$\begin{array}{l}\text { Lung } \\
\text { Cancer }\end{array}$} & \multirow[t]{2}{*}{ After lobectomy } & $\begin{array}{l}\text { 24-Form Chen Tai Chi ( } 10 \text {-minute } \\
\text { warm-up; 10-minute cool-down) }\end{array}$ & Usual care & \multirow{2}{*}{$\begin{array}{l}60 \mathrm{~min}, 3 \\
\text { times } / \text { week } \\
\text { from } 7 \text { to } 8 \\
\text { AM; } 16 \\
\text { weeks }\end{array}$} & \multirow{2}{*}{$\begin{array}{l}\text { The T1/T2 and Tc1/Tc2 ratios show significant } \\
\text { time-by-group interactions (both } \mathrm{P}=.001 \text { ); The } \\
\text { catecholamine level decreased over time in the Tai Chi } \\
\text { group }(\mathrm{P}<0.05 \text { ); No significant changes in the } \beta \text {-EP } \\
\text { levels }\end{array}$} \\
\hline & & & $\mathrm{N}=13 \quad 63.1 \pm 7.9$ & $\mathrm{~N}=14 \quad 59.3 \pm 7.7$ & & \\
\hline \multirow[t]{2}{*}{$\begin{array}{l}\text { Liu et al, } \\
\text { 2015,China[43] }\end{array}$} & \multirow{2}{*}{$\begin{array}{l}\text { Non - } \\
\text { small cell } \\
\text { lung } \\
\text { cancer }\end{array}$} & $\begin{array}{l}\text { Two or more } \\
\text { years after } \\
\text { completion }\end{array}$ & $\begin{array}{l}\text { 24-Form Yang Tai Chi (15-minute } \\
\text { warm-up; 35-minute } \\
\text { practice; } 10 \text {-minute cool-down Period ) }\end{array}$ & \multirow[t]{2}{*}{ Usual care } & \multirow{2}{*}{$\begin{array}{l}60 \mathrm{~min} ; 3 \\
\text { times/week; } \\
6: 30 \text { am to } \\
7: 30 \mathrm{am} ; 16 \\
\text { weeks }\end{array}$} & \multirow[t]{2}{*}{$\begin{array}{l}\text { Significant improvements in cell } \\
\text { proliferation,cytolytic/oncolytic activity against A549 } \\
\text { cells and NK cell percentage }\end{array}$} \\
\hline & & $\begin{array}{l}\text { of surgical } \\
\text { intervention }\end{array}$ & $\mathrm{N}=14 \quad 62.64 \pm 8.35$ & & & \\
\hline
\end{tabular}


Had survived the 24-Form Yang Tai chi (a senior ery for more instructor with 20 years of teaching et al, et al, small cell lung than 2 years and had not received chemotherapy experience, 10-min warm-up; 10-min

cool down)

$\mathrm{N}=13 \quad 63.07 \pm 7.89$
Usual care(not to modify their daily life activity

routine, including diet and physical activity)

$\mathrm{N}=14 \quad 59.27 \pm 7.68$.
$60 \mathrm{~min} \cdot 3$

times /

week;

16 weeks
The TCC participants showed a significantly lowe increment in the expression of CD55 $(p<0.05)$ as compared to the control group. No significant

between-group differences were found in the $\mathrm{CD} 4^{+}: \mathrm{CD} 8$ ratio or CD59 expression. There were also no significan

correlations among the changes in CRPs or T lymphocyte subpopulations, either 
Table 2 Type of Tai Chi used in Studies

\begin{tabular}{|c|c|c|c|}
\hline $\begin{array}{l}\text { Type of } \\
\text { Tai Chi }\end{array}$ & Main Postures & Characteristics & Studies \\
\hline $\begin{array}{l}\text { 24-Form } \\
\text { Chen }\end{array}$ & $\begin{array}{l}\text { 1) Commencing 2)Warrior Pounds the Mortar 3)Tie the Coat Leisurely 4) Six } \\
\text { Sealing and Four Closings 5) Single Whip 6) White Crane Spreads Wings 7) } \\
\text { Walk Obliquely 8) Brush Knees 9) Twist Steps 10) Pat On the Foot With Both } \\
\text { Hands 11) Golden Rooster Stands On One Leg-Left and Right 12)Inverted } \\
\text { flower Dance Sleeves 13) Overturn The Ocean Waves 14) Kick Twice 15) } \\
\text { Girls Shuttling 16) Smooth Elbow } 17 \text { ) Wrapping Fire Crackers 18)Fist } \\
\text { Protects Heart 19) Wear Elbows 20) Tie the Coat Leisurely 21)Cloud Hands } \\
\text { 22)Cannon Over the Head 23)Warrior Pounds the Mortar 24) Closing } \\
\text { Reference: } \\
\text { (1)Guo Chuanguang. Chen Tai Chi simple 24-style [M]. Chengdu: Chengdu } \\
\text { Times Press .2010. } \\
\text { (2) Wushu ed. Taijiquan teaching and training English-Chinese bilingual } \\
\text { teaching [M] Beijing: Beijing Sport University Press .2009. }\end{array}$ & $\begin{array}{c}\text { Emphasizes strong } \\
\text { explosive power and quick } \\
\text { movements, }\end{array}$ & Wang et al ,2013,China[42] \\
\hline $\begin{array}{l}\text { 24-Form } \\
\text { Yang }\end{array}$ & $\begin{array}{l}\text { 1) Commencing 2) Splitting the Wild Horse's Mane on Both Side 3) White } \\
\text { Crane Spreads Wings 4) Brush Knee and Twist Steps on Both Side 5) Playing } \\
\text { the Pipa 6) Repulse Monkey 7) Grasp the Bird's Tail -Lift 8) Grasp the Bird's } \\
\text { Tail-Right 9) Single Whip 10) Clouds Hands 11) Single Whip 12) Patting a } \\
\text { High Horse 13) Kicking with the Right Heel 14) Strike Ears with Both Fists } \\
\text { 15) Turn and Kick with Left Heel 16) Push Down and Stand on the Left Foot } \\
\text { 17) Push Down and Stand on the Right Foot 18) Working with a Shuttle 19) } \\
\text { Needle to Bottom of the Sea 20) Flashing the Arm 21) Turn, Deflect, Parry } \\
\text { and Punch 22) Withdraw and Push 23) Crossing Hands 24) Closing } \\
\text { Reference } \\
\text { (1) Li Huilin. Yang Taiji simple 24-boxing [M]. Chengdu: Chengdu Times Publishing } \\
\text { House .2008 } \\
\text { (2) Zhou Qingjie . Taiji Taiji sword practice guide [M] Beijing: Chinese People's }\end{array}$ & $\begin{array}{l}\text { gentle and soothing, } \\
\text { emphasizing the } \\
\text { coordination between } \\
\text { breath and movement. }\end{array}$ & $\begin{array}{l}\text { Sun XY et al, 2012[24] } \\
\text { Wang YL et al, 2012[25] , } \\
\text { Xiao H et al, 2013[27], Lv } \\
\text { F et al ,2015[28], Sprod et } \\
\text { al ,2012[30], Mustian et } \\
\text { al,2006[32], Mustian et } \\
\text { al ,2008[33], Janelsins et } \\
\text { al,2011[35] , Jiang MY et } \\
\text { al, 2013[37], Peppone et } \\
\text { al ,2010[40], Liu et } \\
\text { al,2015[43] , Zhang et } \\
\text { al,2013[44] }\end{array}$ \\
\hline
\end{tabular}


Public Security University Press .2010.

\begin{tabular}{|c|c|c|c|}
\hline $\begin{array}{l}\text { 10-Form } \\
\text { Yang }\end{array}$ & $\begin{array}{l}\text { Including movement one to ten, and twenty-four of 24-Form Yang, with the } \\
\text { ninth and tenth movement order reversed } \\
\text { Reference: } \\
\text { (1) Su Jianming, Xian Hui. College Wushu bilingual tutorial [M]. Kunming: } \\
\text { Yunnan University Press .2012 } \\
\text { (2) Zhou Qingjie. Taiji Taiji sword practice guide [M] Beijing: Chinese } \\
\text { People's Public Security University Press .2010. }\end{array}$ & $\begin{array}{l}\text { Gentle and soothing, } \\
\text { emphasizing the } \\
\text { coordination between } \\
\text { breath and movement. }\end{array}$ & Larkey et al,2016 [31] \\
\hline $\begin{array}{c}\text { Tai Chi } \\
\text { Chih } \\
\text { Movements }\end{array}$ & $\begin{array}{l}\text { 1) Rocking Motion 2) Bird Flaps its Wings 3) Around the Platter 4) Around } \\
\text { the Platter Variation 6) Bass Drum 7) Daughter on the Mountaintop 8) Carry } \\
\text { the Ball to the Side 9) Push Pull 10) Pulling in the Energy 11) Pulling Taffy } \\
\text { 12) Pulling Taffy - Anchor 13) Pulling Taffy-Wrist Circles 14) Pulling Taffy- } \\
\text { Perpetual Motion 15) Working the Pulley 16) Light at the Top of the Head 17) } \\
\text { Joyous Breath 18) Passing Clouds 19) Six Healing Sounds 20) Cosmic } \\
\text { Consciousness Pose } \\
\text { Campo et al ,2013[24], Campo et al ,2015,[39] }\end{array}$ & & $\begin{array}{l}\text { Campo et al ,2013[29], Campo } \\
\text { et al ,2015[36] }\end{array}$ \\
\hline
\end{tabular}


Table 3 The Effects of Tai Chi among cancer survivors

\begin{tabular}{|c|c|c|c|c|c|c|c|}
\hline \multirow[t]{2}{*}{ Domains } & \multirow[t]{2}{*}{ Intervention } & \multirow[t]{2}{*}{ Control } & \multirow{2}{*}{$\begin{array}{c}\text { Assessment } \\
\text { time point }\end{array}$} & \multirow{2}{*}{$\begin{array}{l}\text { Effect size (Fixed-/ } \\
\text { Random Effects) }\end{array}$} & \multicolumn{2}{|c|}{ Included studies } & \multirow{2}{*}{$\begin{array}{c}\text { Conclusion (i.e. } \\
\text { demonstrating benefits } \\
\text { of Tai-Chi) }\end{array}$} \\
\hline & & & & & $\begin{array}{l}\text { No. of } \\
\text { studies }\end{array}$ & $\begin{array}{c}\text { No. of } \\
\text { particip } \\
\text { ants }\end{array}$ & \\
\hline \multicolumn{8}{|l|}{ Quality of life (QOL) } \\
\hline Physical domain of QOL & Tai Chi & $\begin{array}{c}\text { Rehabilitation } \\
\text { training }(\mathrm{n}=5) / \text { aerobic } \\
\text { exercise/sham } \\
\text { qigong/standard } \\
\text { support/health } \\
\text { education }\end{array}$ & 3 Months & $\begin{array}{c}\mathrm{SMD}=0.34(95 \% \mathrm{CI} \\
0.09 \text { to } 0.59)(\mathrm{RE})\end{array}$ & 9 & 679 & Positive \\
\hline Psychological domain of QOL & Tai Chi & $\begin{array}{c}\text { Rehabilitation } \\
\text { training }(\mathrm{n}=5) / \text { aerobic } \\
\text { exercise/sham } \\
\text { qigong/standard } \\
\text { support/health } \\
\text { education }\end{array}$ & 3 Months & $\begin{array}{c}\mathrm{SMD}=0.60(95 \% \mathrm{CI} \\
0.12 \text { to } 1.08)(\mathrm{RE})\end{array}$ & 9 & 681 & Positive \\
\hline
\end{tabular}




\begin{tabular}{|c|c|c|c|c|c|c|c|}
\hline $\begin{array}{l}\text { Social Relationship domain of } \\
\text { QOL }\end{array}$ & Tai Chi & $\begin{array}{c}\text { Rehabilitation } \\
\text { training }(\mathrm{n}=5) / \text { aerobic } \\
\text { exercise } / \text { standard } \\
\text { support/health } \\
\text { education }\end{array}$ & 3 Months & $\begin{array}{l}\mathrm{SMD}=0.26(95 \% \mathrm{CI} \\
-0.25 \text { to } 0.77)(\mathrm{RE})\end{array}$ & 8 & 595 & Inconclusive \\
\hline $\begin{array}{l}\text { Sensitivity analysis of Social } \\
\text { Relationship }\end{array}$ & Tai Chi & $\begin{array}{c}\text { Rehabilitation } \\
\text { training }(\mathrm{n}=5) / \text { aerobic } \\
\text { exercise }\end{array}$ & 3 Months & $\begin{array}{c}\mathrm{SMD}=0.56(95 \% \mathrm{CI} \\
0.10 \text { to } 1.03)(\mathrm{RE})\end{array}$ & 6 & 522 & Positive \\
\hline $\begin{array}{l}\text { Subjective Feeling with } \\
\text { Quality of Life }\end{array}$ & Tai Chi & $\begin{array}{l}\text { Rehabilitation } \\
\text { training }\end{array}$ & 3 Months & $\begin{aligned} \mathrm{MD}= & 0.47(95 \% \mathrm{CI} 0.15 \\
& \text { to } 0.80)(\mathrm{FE})\end{aligned}$ & 3 & 268 & Positive \\
\hline $\begin{array}{lll}\text { Subjective } & \text { Feeling } \\
\text { Health } & & \end{array}$ & Tai Chi & $\begin{array}{l}\text { Rehabilitation } \\
\text { training }\end{array}$ & 3 Months & $\begin{aligned} \mathrm{MD}= & 0.42(95 \% \mathrm{CI} 0.08 \\
& \text { to } 0.76)(\mathrm{FE})\end{aligned}$ & 3 & 267 & Positive \\
\hline Environment & Tai Chi & $\begin{array}{l}\text { Rehabilitation } \\
\text { training }\end{array}$ & 3 Months & $\begin{aligned} \mathrm{MD}= & 0.50(95 \% \mathrm{CI}-0.50 \\
& \text { to } 1.50)(\mathrm{FE})\end{aligned}$ & 3 & 267 & Inconclusive \\
\hline Functional Well-being & Tai Chi & $\begin{array}{l}\text { Rehabilitation } \\
\text { training/aerobic } \\
\text { exercise }\end{array}$ & 3 Months & $\begin{aligned} \mathrm{MD}= & 2.74(95 \% \mathrm{CI} 2.03 \\
& \text { to } 3.45)(\mathrm{RE})\end{aligned}$ & 2 & 155 & Positive \\
\hline Additional Concerns & Tai Chi & $\begin{array}{l}\text { Rehabilitation } \\
\text { training/aerobic } \\
\text { exercise }\end{array}$ & 3 Months & $\begin{aligned} \mathrm{MD}= & 1.58(95 \% \mathrm{CI} 0.92 \\
& \text { to } 2.24)(\mathrm{FE})\end{aligned}$ & 2 & 156 & Positive \\
\hline
\end{tabular}




\begin{tabular}{|c|c|c|c|c|c|c|c|}
\hline Role-Physical & Tai Chi & $\begin{array}{l}\text { Rehabilitation } \\
\text { training /standard } \\
\text { support/health } \\
\text { education }\end{array}$ & 3 Months & $\begin{aligned} \mathrm{MD}= & 4.56(95 \% \mathrm{CI}-6.21 \\
& \text { to } 15.33)(\mathrm{RE})\end{aligned}$ & 3 & 172 & Inconclusive \\
\hline Body Pain & Tai Chi & $\begin{array}{l}\text { Rehabilitation } \\
\text { training /standard } \\
\text { support/health } \\
\text { education }\end{array}$ & 3 Months & $\begin{aligned} \mathrm{MD}= & 3.75(95 \% \mathrm{CI}-1.37 \\
& \text { to } 8.86)(\mathrm{RE})\end{aligned}$ & 3 & 172 & Inconclusive \\
\hline General Health & Tai Chi & $\begin{array}{l}\text { Rehabilitation } \\
\text { training /standard } \\
\text { support/health } \\
\text { education }\end{array}$ & 3 Months & $\begin{array}{l}\mathrm{MD}=0.05 \quad(95 \% \mathrm{CI} \\
-4.53 \text { to } 4.63)(\mathrm{RE})\end{array}$ & 3 & 172 & Inconclusive \\
\hline Vitality & Tai Chi & $\begin{array}{l}\text { Rehabilitation } \\
\text { training /standard } \\
\text { support/health } \\
\text { education }\end{array}$ & 3 Months & $\begin{array}{l}\mathrm{MD}=5.41 \quad(95 \% \mathrm{CI} \\
-5.06 \text { to } 15.87)(\mathrm{RE})\end{array}$ & 3 & 172 & Inconclusive \\
\hline Role-emotional & Tai Chi & $\begin{array}{l}\text { Rehabilitation } \\
\text { training /standard } \\
\text { support/health } \\
\text { education }\end{array}$ & 3 Months & $\begin{aligned} \mathrm{MD}= & 1.38(95 \% \mathrm{CI}-1.83 \\
& \text { to } 4.58)(\mathrm{RE})\end{aligned}$ & 3 & 172 & Inconclusive \\
\hline
\end{tabular}




\begin{tabular}{|c|c|c|c|c|c|c|c|}
\hline Limb function & Tai Chi & $\begin{array}{c}\text { Rehabilitation } \\
\text { training }(\mathrm{n}=4) / \text { aerobic } \\
\text { exercise }\end{array}$ & 3 Months & $\begin{array}{l}\mathrm{SMD}=1.19(95 \% \mathrm{CI} \\
0.63 \text { to } 1.75)(\mathrm{RE})\end{array}$ & 5 & 465 & Positive \\
\hline $\begin{array}{l}\text { Sensitive analysis of limb } \\
\text { function }\end{array}$ & Tai Chi & $\begin{array}{c}\text { Rehabilitation } \\
\text { training }(n=3) / \text { aerobic } \\
\text { exercise }\end{array}$ & 3 Months & $\begin{array}{c}\mathrm{SMD}=0.87(95 \% \mathrm{CI} \\
0.66 \text { to } 1.09)(\mathrm{RE})\end{array}$ & 4 & 375 & Positive \\
\hline $\begin{array}{l}\text { Muscular Strength of upper } \\
\text { limbs }\end{array}$ & Tai Chi & $\begin{array}{c}\text { Rehabilitation } \\
\text { training }(n=3) / \text { psycho } \\
\text { logical therapy }\end{array}$ & 3 Months & $\begin{array}{c}\mathrm{SMD}=0.49 \quad(95 \% \mathrm{CI} \\
0.16 \text { to } 0.81)(\mathrm{RE})\end{array}$ & 4 & 330 & Positive \\
\hline$I L-6$ & Tai Chi & $\begin{array}{l}\text { psychological } \\
\text { therapy /standard } \\
\text { support }\end{array}$ & 3 Months & $\begin{aligned} \mathrm{MD}= & 2.21(95 \% \mathrm{CI} 0.74 \\
& \text { to } 3.68)(\mathrm{FE})\end{aligned}$ & 2 & 38 & Inconclusive \\
\hline Cortisol & Tai Chi & $\begin{array}{c}\text { Health } \\
\text { education/standard } \\
\text { support }\end{array}$ & 3 Months & $\begin{array}{l}\mathrm{MD}=-0.09 \quad(95 \% \mathrm{CI} \\
-0.16 \text { to }-0.02)(\mathrm{FE})\end{array}$ & 2 & 73 & Positive \\
\hline$C R F$ & Tai Chi & $\begin{array}{l}\text { Usual care/sham } \\
\text { qigong/cognitive } \\
\text { behavioral therapy }\end{array}$ & $\begin{array}{l}\text { Mainly } 3 \\
\text { Months }\end{array}$ & $\begin{array}{c}\mathrm{SMD}=-0.04 \quad(95 \% \mathrm{CI} \\
-0.30 \text { to } 0.22)(\mathrm{FE})\end{array}$ & 3 & 234 & Inconclusive \\
\hline Sensitive analysis of $\mathrm{CRF}$ & Tai Chi & $\begin{array}{l}\text { Usual care/sham } \\
\text { qigong }\end{array}$ & $\begin{array}{l}\text { One and } \\
\text { Three } \\
\text { Months }\end{array}$ & $\begin{array}{c}\mathrm{SMD}=-0.37 \quad(95 \% \mathrm{CI} \\
-0.70 \text { to }-0.04)(\mathrm{FE})\end{array}$ & 2 & 144 & Positive \\
\hline
\end{tabular}




\begin{tabular}{|c|c|c|c|c|c|c|c|}
\hline Sleep quality & Tai Chi & $\begin{array}{l}\text { Usual care/sham } \\
\text { qigong/ cognitive } \\
\text { behavioral therapy }\end{array}$ & $\begin{array}{l}\text { Mainly } 3 \\
\text { Months }\end{array}$ & $\begin{array}{c}\mathrm{SMD}=0.26 \\
(95 \% \mathrm{CI}-0.02 \text { to } 0.53) \\
(\mathrm{FE})\end{array}$ & 3 & 218 & Inconclusive \\
\hline $\begin{array}{l}\text { Sensitive analysis of Sleep } \\
\text { quality }\end{array}$ & Tai Chi & $\begin{array}{l}\text { Usual care/sham } \\
\text { qigong/ }\end{array}$ & $\begin{array}{c}\text { One and } \\
\text { Three } \\
\text { Months }\end{array}$ & $\begin{array}{l}\mathrm{SMD}=-0.37(95 \% \mathrm{CI} \\
-0.72 \text { to }-0.02)(\mathrm{FE})\end{array}$ & 2 & 128 & Positive \\
\hline
\end{tabular}




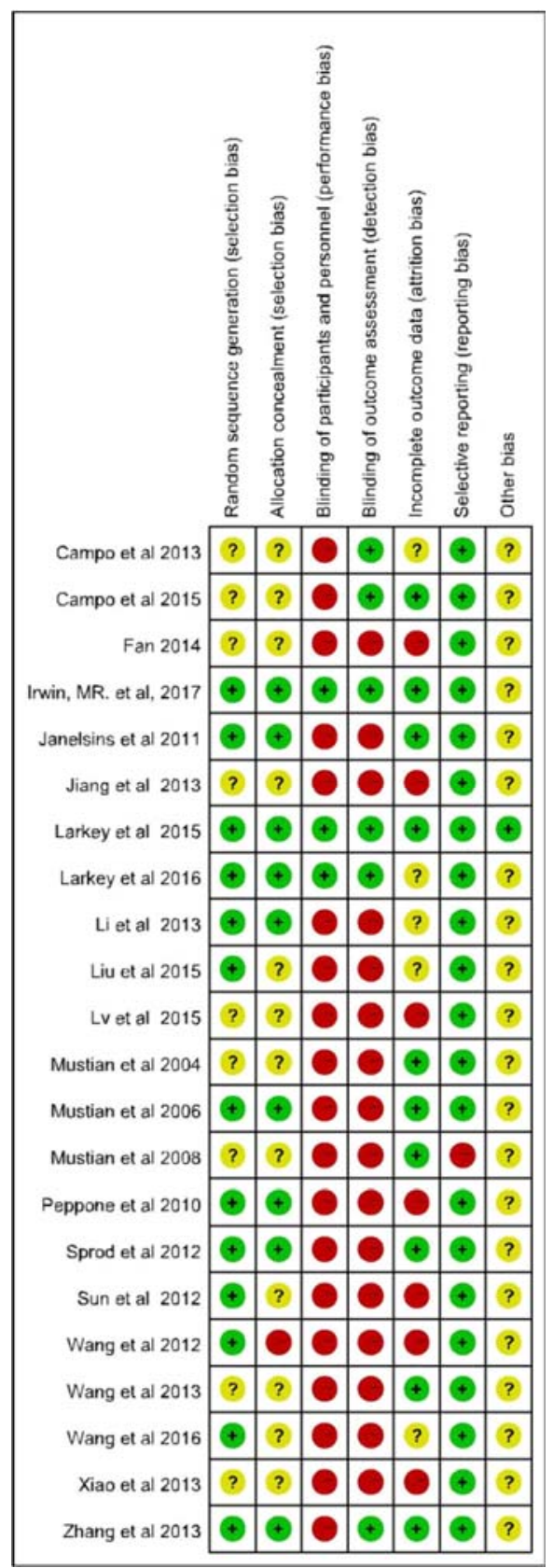

- low risk of bias

- high risk of bias

? unclear risk of bias

Fig.2 Risk of bias summary 
Table 4. Risk of bias summary

\begin{tabular}{|c|c|c|c|c|c|c|c|c|c|c|c|}
\hline \multicolumn{7}{|c|}{ Quality assessment } & \multicolumn{2}{|c|}{ No of patients } & \multirow{2}{*}{$\begin{array}{l}\text { Absolute Effect } \\
\qquad(95 \% \mathrm{Cl})\end{array}$} & \multirow[b]{2}{*}{ Quality } & \multirow[b]{2}{*}{ Importance } \\
\hline No of studies & Design & $\begin{array}{c}\text { Risk of } \\
\text { bias }\end{array}$ & Inconsistency & Indirectness & Imprecision & $\begin{array}{c}\text { Other } \\
\text { consideratio }\end{array}$ & Tai Chi & Control & & & \\
\hline \multicolumn{12}{|c|}{ Tai Chi for Quality of Life } \\
\hline 9 & $\begin{array}{l}\text { randomised } \\
\text { trials }\end{array}$ & serious $^{1}$ & serious $^{2}$ & $\begin{array}{l}\text { no serious } \\
\text { indirectness }\end{array}$ & $\begin{array}{l}\text { no serious } \\
\text { imprecision }\end{array}$ & none & 331 & 348 & $\begin{array}{c}\text { SMD: } 0.34 \\
(-0.59,-0.09)\end{array}$ & $\begin{array}{r}\oplus \oplus \mathrm{OO} \\
\text { LOW }\end{array}$ & CRITICAL \\
\hline 5 & $\begin{array}{l}\text { randomised } \\
\text { trials }\end{array}$ & serious $^{1}$ & serious $^{2}$ & $\begin{array}{l}\text { no serious } \\
\text { indirectness }\end{array}$ & $\begin{array}{l}\text { no serious } \\
\text { imprecision }\end{array}$ & none & 225 & 240 & $\begin{array}{l}\text { SMD: } 1.19 \\
(0.63,1.75)\end{array}$ & $\begin{array}{c}\oplus \oplus \oplus \mathrm{O} \\
\text { MODER } \\
\text { ATE }\end{array}$ & IMPORTANT \\
\hline \multicolumn{12}{|l|}{ Tai Chi for IL-6 } \\
\hline 2 & $\begin{array}{l}\text { randomised } \\
\text { trials }\end{array}$ & serious $^{3}$ & $\begin{array}{l}\text { no serious } \\
\text { inconsistency }\end{array}$ & $\begin{array}{l}\text { no serious } \\
\text { indirectness }\end{array}$ & serious $^{4}$ & none & 18 & 20 & MD :2.21 & $\begin{array}{c}\oplus \oplus \mathrm{OO} \\
\text { LOW }\end{array}$ & IMPORTANT \\
\hline 2 & $\begin{array}{l}\text { randomised } \\
\text { trials }\end{array}$ & $\begin{array}{l}\text { no serious } \\
\text { risk of bias }\end{array}$ & $\begin{array}{l}\text { no serious } \\
\text { s inconsistency }\end{array}$ & $\begin{array}{l}\text { no serious } \\
\text { indirectness }\end{array}$ & serious $^{4}$ & none & 38 & 35 & MD :0.09 & $\begin{array}{c}\oplus \oplus \oplus \mathrm{O} \\
\text { MODER }\end{array}$ & IMPORTANT \\
\hline
\end{tabular}




\begin{tabular}{|c|c|c|c|c|c|c|c|c|c|c|c|}
\hline 2 & $\begin{array}{l}\text { randomised } \\
\text { trials }\end{array}$ & serious $^{3}$ & $\begin{array}{l}\text { no serious } \\
\text { inconsistency }\end{array}$ & $\begin{array}{l}\text { no serious } \\
\text { indirectness }\end{array}$ & $\begin{array}{l}\text { no serious } \\
\text { imprecision }\end{array}$ & none & 115 & 119 & $\begin{array}{l}\text { SMD: }-0.04 \\
(-0.70,-0.4)\end{array}$ & $\begin{array}{c}\oplus \oplus \oplus \mathrm{O} \\
\text { MODER } \\
\text { ATF }\end{array}$ & IMPORTANT \\
\hline \multicolumn{12}{|c|}{ Tai Chi for Sleep quality } \\
\hline 2 & $\begin{array}{l}\text { randomised } \\
\text { trials }\end{array}$ & serious $^{1}$ & $\begin{array}{l}\text { no serious } \\
\text { inconsistency }\end{array}$ & $\begin{array}{l}\text { no serious } \\
\text { indirectness }\end{array}$ & serious $^{4}$ & none & 106 & 112 & $\begin{array}{l}\text { SMD:0.26 } \\
(-0.93,-0.07)\end{array}$ & $\begin{array}{l}\oplus \oplus \mathrm{OO} \\
\text { LOW }\end{array}$ & IMPORTANT \\
\hline
\end{tabular}

Note: 1 There were no details on blinding and the randomisation method. Although it was difficult to blind to patients and researchers, outcome assessors should be blinded. 22 There was high heterogeneity ;3 Details on blinding and randomisation method were missing; 4 The sample size was too small 


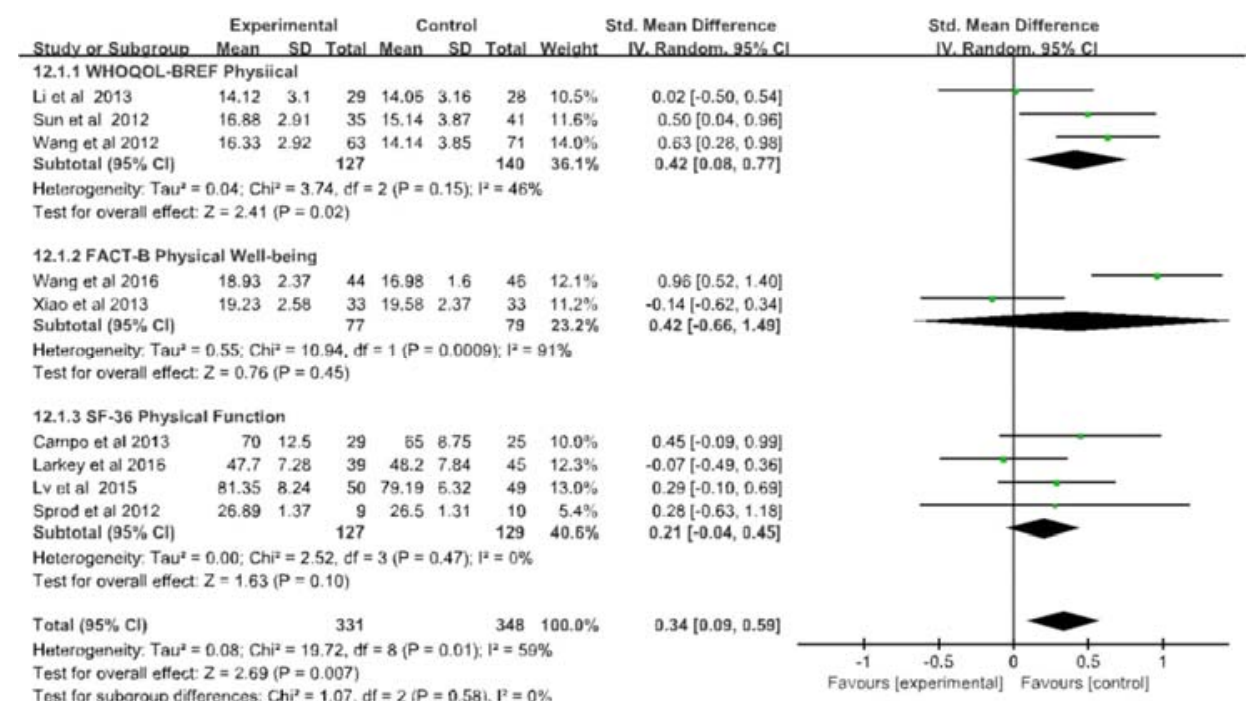

Fig.1.1 Forest plot of Physical of QOL

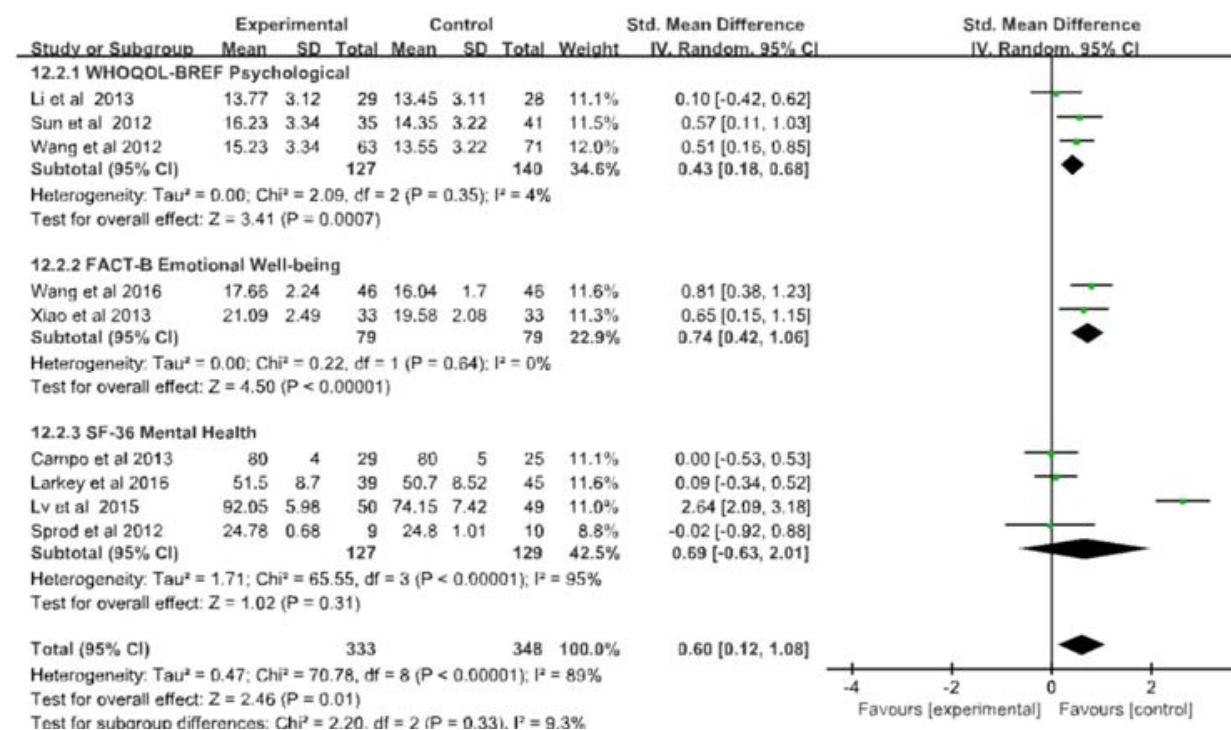

Fig.1.2 Forest plot of Psychological of QOL

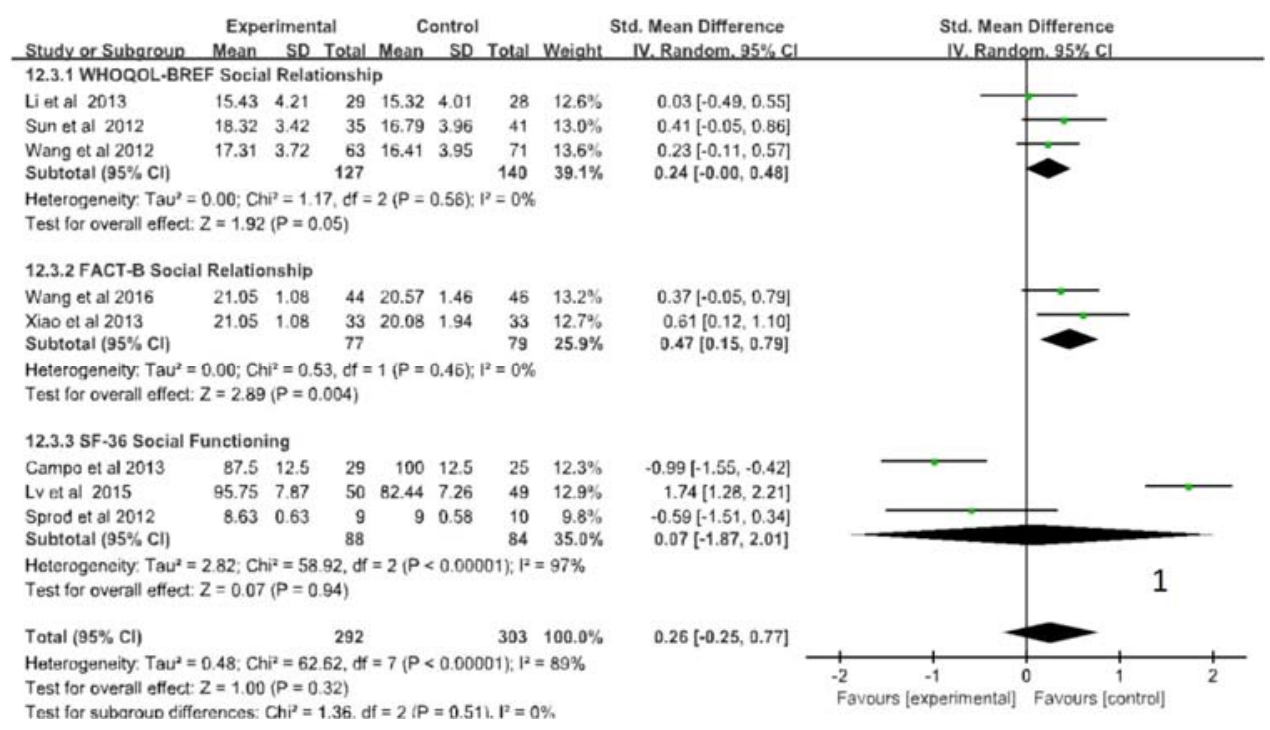

Fig.1.3 Forest plot of Social Relationship of QOL

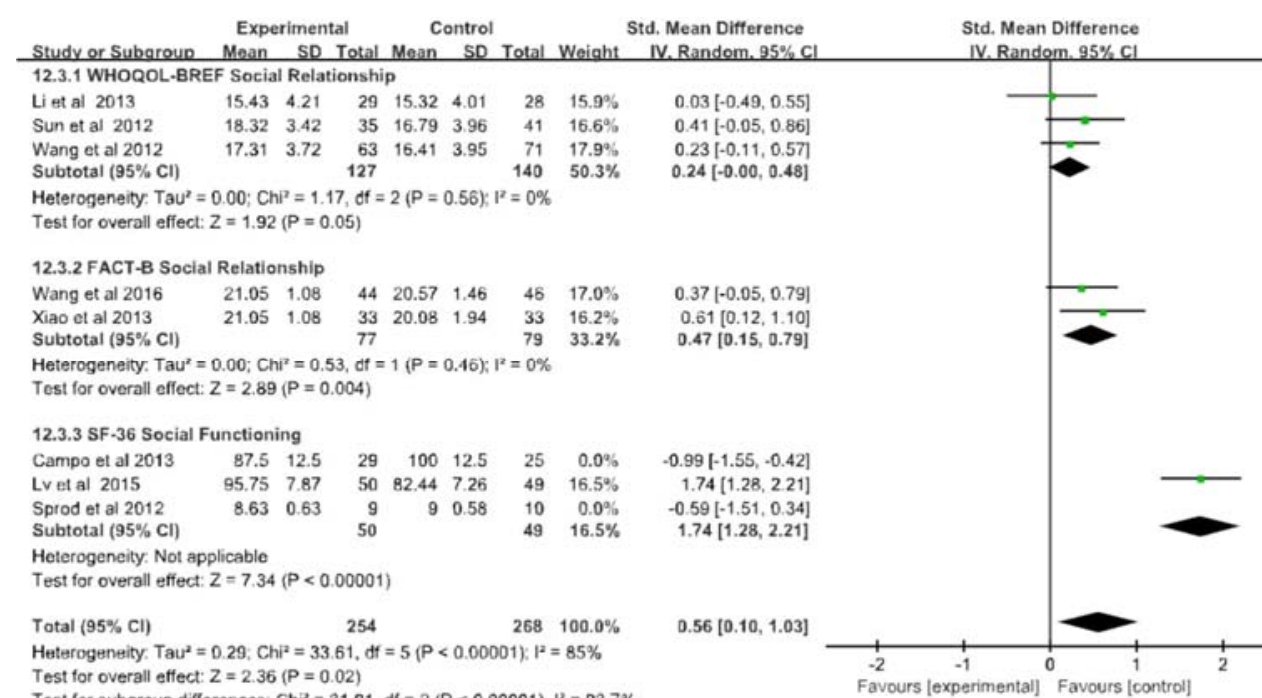

Fig.1.4 Sensitivity analysis of Social Relationship

Figure 4 Forest plots of the impact of Tai Chi on QOL 
Figure 2 Forest plots of the impact of Tai Chi on Limb function

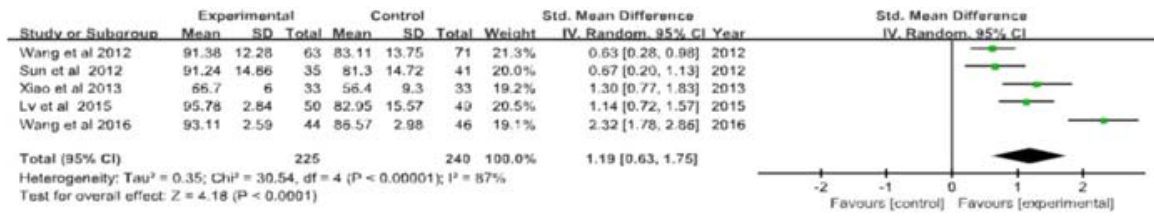

Fig.2.1 Forest plot of Upper limb function

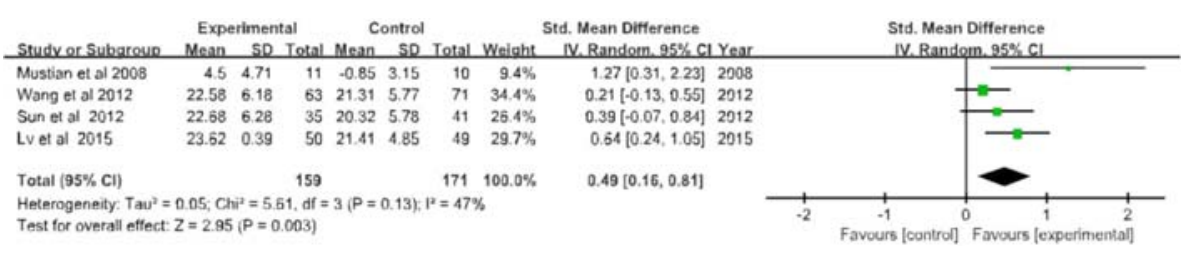

Fig.2.3 Forest plot of Muscular strength of upper limbs

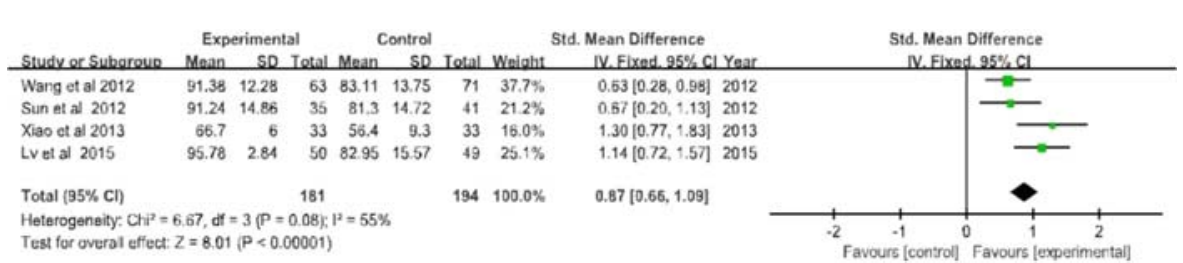

Fig.2.2 Sensitivity analysis of limb function 
Figure 3 Forest plots of the impact of Tai Chi on Physiological indicators

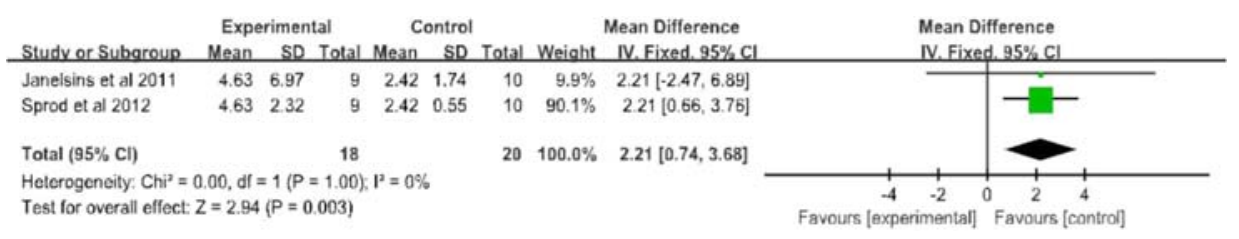

Fig.3.1 Forest plot of IL-6

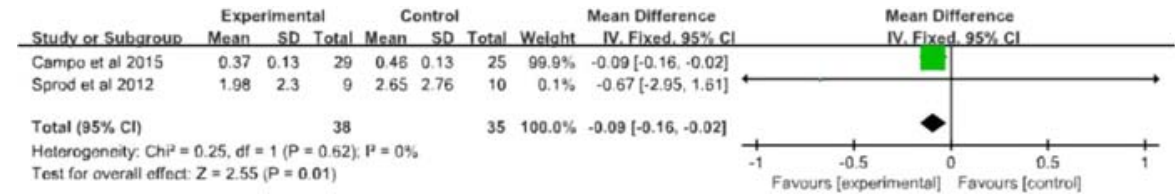

Fig.3.2 Forest plot of Cortisol

Figure 4 Forest plots of the impact of Tai Chi on CRF

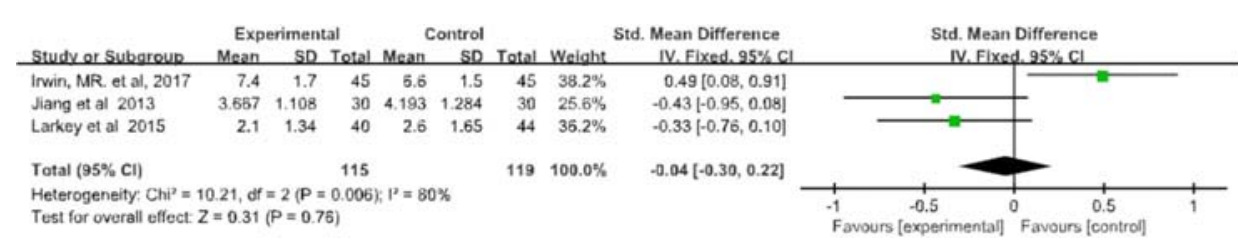

Fig.4.1 Forest plot of CRF

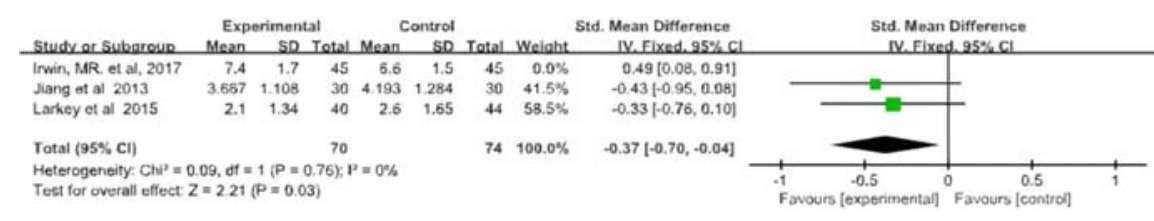

Fig.4.2 Sensitivity analysis of CRF 
Figure 5 Forest plots of the impact of Tai Chi on sleep

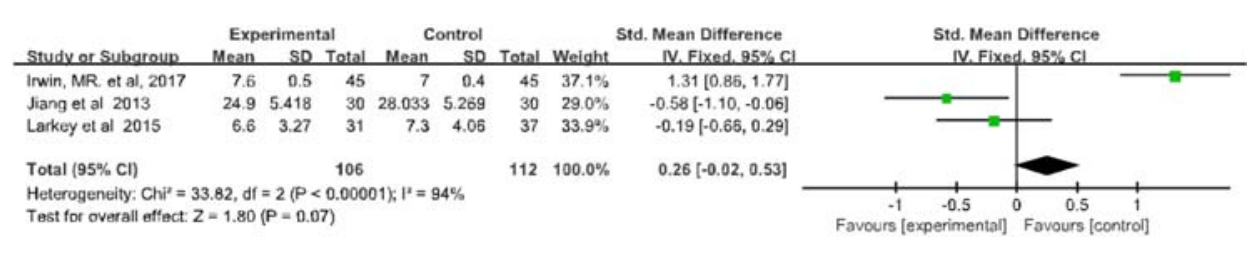

Fig. 5.1 Forest plots of the impact of Tai Chi on Sleep

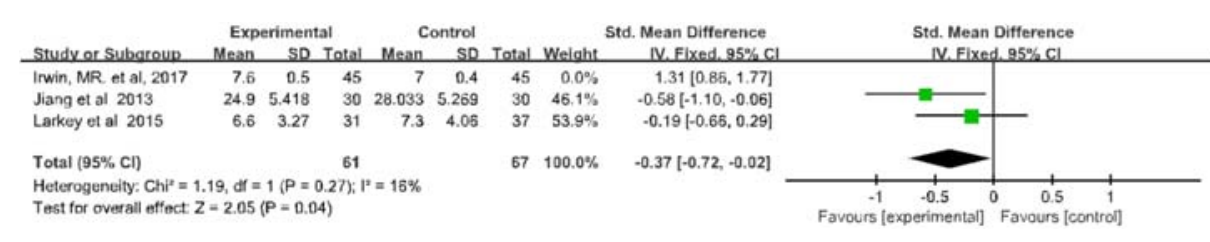

Fig. 5.2 Sensitivity analysis of Sleep 